\title{
24
}

PROJECT MUSE

\section{Coloniality and the Rise of Liberation Thinking during the} Sixteenth Century

Thomas Ward

Published by Arc Humanities Press

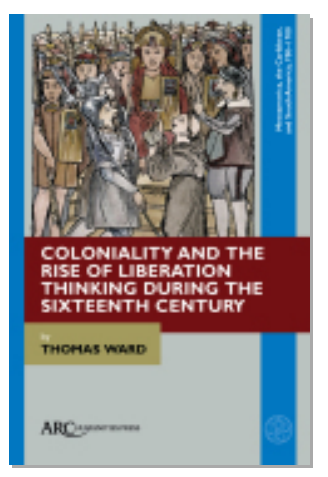

Ward, Thomas.

Coloniality and the Rise of Liberation Thinking during the Sixteenth Century.

Arc Humanities Press, 2021.

Project MUSE. muse.jhu.edu/book/79367.

$\Rightarrow$ For additional information about this book

https://muse.jhu.edu/book/79367 


\section{Chapter I}

\section{EVERYDAY COLONIALITY AND EARLY SOCIAL SLAVERY THEORY*}

THIS BOOK IS about certain features of quotidian colonialism imposed on people and the liberating antidote to these features. Colonialism is that aspect of imperialism that directly impacts the people, societies, institutions, and cultures coming under imperial sway. Before we can get to the antidote, we must understand the contagion. Colonialism occurs, of course, when a political and economic force from one country invades and takes control of another country by force and by attaining hegemony over the people residing there. There is a religious, racial, cultural, or ethnic component to imperial activities if the first country differs from the second one in this regard. When the colonizing country, for any reason, and after any amount of time, quits the colonized country, it leaves behind a residue considered internal colonialism. Sometimes racial, ethnic, or religious variance makes this variety of colonialism obvious. This kind of hegemonic activity within the borders of one country may also be rooted in long-ago migrations, the details of which may be forgotten in time, or they may have resulted from more recent foreign contacts. ${ }^{1}$ Here we are interested in the transatlantic element, first as an element that crosses the ocean (external colonialism) then as the formerly transatlantic element that has taken root in Abya Yala (internal colonialism).

The moment the nation, any nation, establishes a scheme of rank within it, there follows necessarily the need for subservience. For millennia, human societies have unambiguously developed methods of subjugating their own peers as well as people from other groups. There are countless forms of achieving hegemony in social organization. Among the basic social determinants are hierarchies organized by dint of ethnicity, class, memory of the past, conceptualizations of the present, religion, language, gender, and the status of immigrating and emigrating peoples. While ethnicity, memory, religious conviction, and language can have a liberating quality to them, their positive deployment subsides in the face of political and religious power, utilitarianism, or even worse, greed. Among the most egregious of politically imposed strata are diverse forms of slavery and other involuntary labor practices. The subordinating features of ethnicity, gender, language, institutional religion, economics, class, and hegemonic interactions

* This chapter's genesis can be found in a paper during the celebrations of the Quincentennial of Christopher Columbus's arrival in the Indies, "Hacia un nuevo concepto de esclavitud en el Renacimiento: el paso de Colón a Moro, Erasmo y Las Casas," 28th Congress of the Instituto Internacional de Literatura Iberoamericana, Brown University, June 1990. Actas Colombinas, Universidad de la Serena (Chile) 2, no. 5 (1992): 39-45, and expanded/translated, "Toward a Concept of Unnatural Slavery during the Renaissance: A Review of Primary and Secondary Sources," Revista Interamericana de Bibliografía 42, no. 2 (1992): 259-79.

I For further discussion on the varieties of colonialism, see Ward, Decolonizing Indigeneity, 1-10. 
between people imposed varying forms of control in nations, and especially in the social relations of colonized peoples in the very first transatlantic societies.

We can view the sixteenth century as a large social laboratory, perhaps the largest ever, because during that period, the Spanish Empire put in place the structures that gave rise to a new transatlantic modus operandi. This does not mean that the new system was harmonious although those characteristics ran through it. Newly installed social hierarchies reorganized old social hierarchies, sometimes through trial and error. Some would stick and become lasting social and legal norms. Enrique Dussel puts it this way, "The present world reality manifests in its structure a lack of equilibrium that has existed for five hundred years." ${ }^{2}$ Of the destabilizing forces, which were legion, religion was one of the primary ones. From the beginning of the colonial era that Christopher Columbus inaugurated, Spaniards took to the task of evangelization while they slowly began to construct the material basis of Catholic towns across the hemisphere. In Dussel's words, "Evangelization involved not only personal or individual conversion, but also social and community transformation." ${ }^{3}$ Europeans had the newly subordinated peoples construct churches, cathedrals, monasteries, parish houses, and other buildings necessary to propagate and foster the faith. It cannot be understated that, as Marcel Velázquez Castro reminds us, religion eventually came to be at the center of colonial life. ${ }^{4}$ Spaniards, and later their descendants known as Criollos, were fervent Catholics and uniformly believed that their slaves and all the peoples they were folding into their empire should be Catholic. The dissemination of the illuminating light of the words of Jesus Christ sometimes blinded out the fact that there also existed the gloomy reality of human servitude.

During the early stages of the Spanish imperial thrust, when, as Immanuel Wallerstein frames it, "the modern class system began to take its shape," framework began taking form, with the conquering classes from Europe replacing the native caciques, tlatoque (sing. tlatoani), and kurakakuna (sing. kuraka), or other types of hereditary lords of the hemisphere. Soon thereafter, people of mixed Eurindian descent and the Criollos appeared side by side. This middle social stratum in turn would represent a higher social rank than the former Amerindian elites who now found themselves competing with nonaristocratic compatriots to maintain their place on the newly formed third rung. In the lower social strata, up and down the hemisphere, resided the masses of runa, macehualli, or other classes of everyday people facing coloniality. These were the tributary and peon classes. Just a step lower, or in some cases on the same rung, were the slave estates, consisting of peoples of Amerindian origin or who were being trafficked from Africa. ${ }^{6}$ Yet this hierarchical pyramid was not quite set in stone.

2 Dussel, $A$ History of the Church, 3.

3 Dussel, A History of the Church, 33.

4 Velázquez Castro, La mirada de los gallinazos, 53.

5 Wallerstein, The Modern World-System, 67.

6 On African slavery in Latin America, see Klein and Vinson III, La esclavitud africana. On Africans and their descendants in Peru, for example, see Aguirre, Breve historia de la esclavitud, Bowser, The African Slave in Colonial Peru, and Kapsoli Escudero, Sublevaciones de esclavos. 
Magnus Mörner, who spent his life studying these echelons, distinguishes three types of "social stratification": caste, estate, and class. Birth regulates caste, an inflexible social order. Class bases itself entirely on "economic differences without legal restrictions on vertical social mobility." The middle ground, estate, is legally determined, yet permitting some "vertical social mobility." Mestizos most likely were associated with class norms. Over time the term "class"-Mörner suggests—becomes more appropriate, since stratification is increasingly associated with accumulated economic power. ${ }^{7}$ Sometimes people from one band passed for people of another, such as when Indigenous people passed as mestizos. Amerindian bondage according to the letter of the law disappeared as the sixteenth century wore on, but not so with chattel slavery, which grew in force during the colonial era.

Since Europeans enslaved Africans who themselves sometimes had been enslaved by other Africans, we know slavery did not originate solely in Abya Yala but was coetaneous with similar practices in the Old World forming a complicated quilt of pro-slavery practices after 1492. Slavery became integral to the Conquest itself. Matthew Restall reminds us, "Africans were ubiquitous ... to the entire endeavor of Spanish invasion and colonization in the Americas." ${ }^{8}$ During the first decades of transafrican bondage in New World history, chattel slavery complemented Indigenous forms of bondage enshrined in the encomienda and in other forms of cooperative labor, such as the mita and the coatequitl that Spaniards hijacked and repurposed as forms of forced labor. Later it surpassed Indigenous forms of subordination in both intensity and in cruelty. As Seijas and Sierra Silva argue, "slavery and the slave trade were vital to the colonial economy of Central Mexico during the entire seventeenth century." It took only decades for Africans and their descendants to become the most abused raw ingredient of an expanding imperial society shared with Europeans, Amerindians, and their descendants. Some of the period's chronicles are helpful for understanding this situation and for remembering aspects conveniently forgotten.

Pedro de Cieza de León's Crónica del Perú, which, besides the wealth of anthropological information on Indigenous peoples it contains, reveals a limited degree of information on transafrican slaves. According to Carlos Araníbar, Cieza was only fifteen years old when he crossed the Atlantic in search of adventure and he lived such an intensive life that he died at the age of thirty-four, in $1554 .{ }^{10}$ In that interval he wrote the five parts of his Crónica del Perú, consulted by many subsequent historiographical authorities including Inca Garcilaso de la Vega. The representation of transafrican people is an extraordinary, although limited, aspect of his chronicle. While there certainly were black people in the invasion, chroniclers tend to glorify Spanish feats and downplay African (and Indigenous) activities. Restall comments on this situation: "Because the majority of such Africans arrived as slaves, and because of their subordinate status in the

7 Mörner, Race, 7, 54.

8 Restall, Seven Myths, 52-53.

9 Seijas and Sierra Silva, "The Persistence of the Slave Market," 307.

10 Araníbar, "Introducción," ix. 
increasingly ethnocentric Castilian worldview, the widespread and central role of blacks was consistently ignored by Spaniards writing about the conquest." ${ }^{\prime 11}$ Cieza, however, is atypical in this regard. He mentions transafricans sporadically in his text, for example, in the context of mining gold in the lands that became Colombia. To mention one instance among several, the chronicler observes Capitan Jorge Robledo's black [slave] taking possession of an increasing amount of gold. ${ }^{12}$ However, Restall sees this chronicler's depiction of transafricans in the war effort as ambiguous. "Cieza de León never provides the total number of blacks in any one company, nor does he name any of the Africans who fought or traveled with him, but on 19 occasions he mentions their presence."13 These kinds of omissions are verified, for example, when a black man in the Peruvian campaigns saves the day and protects the conquistador Diego de Almagro after he was hit in the eye with a javelin. ${ }^{14}$ Cieza does not even bother to give this historical subject's name. He merely describes circumstances. Those events relating to gold are almost commonplace, as is the multitude of black men who remained unnamed.

After the institution of the imperial system, Afrodescendant slaves suffered consummate objectification like in the case in Peru of Fernández de Córdova who on February 9, 1585 paid on account 3,000 pesos in silver and jewelry, slaves and embroidery as a dowry. ${ }^{15}$ People and things are commodified. Even Inca Garcilaso de la Vega living in Spain purchased, at one point, an eleven-year-old boy, described as a mulatto-morisco. ${ }^{16}$ Around that time, Francisco Loyola (the so-called Lieutenant Nun) states in matter-offact terms that just before he participated in the Chilean campaigns, he received three slaves, two men and a negra who could cook for him. ${ }^{17}$ As with Cieza de León, he gives no name. Further research into early modern records will yield more information on this significant aspect of social organization.

In a general sense, we know that during the heyday of transatlantic slavery, population tended to increase on the European, American, and Asian continents. Inversely, Africa's contracted. Inikori and Engerman, reviewing the research, conclude, "Africa's share of Atlantic basin population declined from about 30\% in 1650 to roughly $10 \%$ in $1850 .{ }^{18}$ Needless to say, there are twentyfold potential reasons for population numbers to fall or rise. After a series of pandemics, an additional factor was most certainly human trafficking. While millions of Nahua, Carib, and Andean peoples unmistakably perished due to the harsh viral, economic, and religious conditions Spaniards imposed on them, Europeans and Africans themselves directly subjected some eighteen million subSaharan Africans to forced migration between the sixteenth and nineteenth centuries.

\section{I Restall, Seven Myths, 52-53.}

12 Cieza de León, Crónica del Perú: primera parte, fol. 27 [xvii], p. 60.

13 Restall, Seven Myths, 60.

14 Cieza de León, Crónica del Perú: tercera parte, fol. 9, p. 27.

I5 Holguín Callo, Poder, corrupción y tortura, 57.

16 Porras Barrenechea, "Nuevos fondos documentales," 44.

17 Erauso, Historia de la Monja Alférez, 102.

18 Inikori and Engerman, "Introduction," 6. 
Of these, some six million were shipped to North Africa or the Middle East, and as many as ten-and-a-half million may have reached the shores of Abya Yala. Over a million-anda-half lost their lives during the Middle Passage across the Atlantic and another four million lost their lives in Africa itself. ${ }^{19}$ These forced migrations would have a specific meaning for the ethnic fabric of Abya Yala.

Regarding the Indigenous population, it fell by what Nathan Wachtel describes as a "vertiginous rate," varying from sheer extinction in the Caribbean to 90 percent on the Mexican plateau, although some of the Andean altiplano peoples fared somewhat better. In Brazil, the population seems to have declined from two-and-a-half million to about 800,000 in the first 100 years of contact. ${ }^{20}$ The central Pacific coast did not fare much better. Robert G. Keith, studying taxation roles, says "the number of tributaries still living in traditional Indian communities in 1575 was about 4 percent of what it had been before the conquest." ${ }^{21}$ Wachtel coins a neologism when he calls this demographic catastrophe a "destructuration." ${ }^{22}$ At the same time, a mass of 2.4 million Europeans arrived in Abya Yala coeval with a whopping 8.4 million Africans who began new lives as chattel slaves. ${ }^{23}$ This ebb and flow of peoples combined with mortality and birth rates created a society radically different from those known in the past.

In a pan-America where the everyday mindset of slavery as "normal" dominated, it is not surprising that the legal chains that held African Americans in poverty were not broken until well after the Enlightenment and political independence. Emancipation, for example, came in Venezuela in 1821, Mexico in 1829, Peru in 1854, the United States of America in 1863, Cuba in 1880, and Brazil in 1888. Tellingly this abolitionist movement came amidst a flurry of re-editions of Bartolomé de las Casas's Brevísima relación de la destrucción de las Indias (The Devastation of the Indies: A Brief Account) in Bogotá, Puebla, Guadalajara, Mexico City and Philadelphia. ${ }^{24}$ Moreover, there were frequent relapses and backtracking. After the abolition for transafricans in Peru, for example, that nation began to import Chinese-speaking debt-bondsmen from Asia, the so-called coolies, adding yet another ethnic component to society. As late as the 1890s, the Yaquis, rebellious in their demand that the Mexican state restore Indigenous autonomy, fell into the category Thomas More would describe as slavery-as-punishment. The government responded by "deporting the Yaquis to work to death as virtual slave laborers on the sisal plantations of the Yucatán." ${ }^{25}$ John Kenneth Turner approximates the number of

19 Manning, “The Slave Trade," 118.

20 Weaver, Latin America in the World Economy, 21.

21 Keith, Conquest and Agrarian Change, 42.

22 Wachtel, "The Indian and the Spanish Conquest," 212.

23 Bailey, "The Slave(ry) Trade," 208. These figures differ a bit from Manning's, but they are still significant numbers.

24 Hanke, Bartolomé, 70.

25 Weatherford, Indian Givers, 160; Hu-Dehart, “Development and Rural Rebellion," 91. 
chattel slaves in the Yucatán in the last decade before the Mexican Revolution as 8,000 Yaquis, 3,000 Asians, and between 100,000 and 125,000 Mayas. ${ }^{26}$

Here, we review sixteenth-century slavery, weighing the different theories and praxis that underpin its variants, and theorize the social and psychological conditions that result from it. First, we see how slavery, its physical condition, its intellectual foundation, and the psychology that arises coalesce into a situation that affects distinct classes of people. We call this situation coloniality. Second, we examine the Nahua system of slavery and how the Spanish system, which was not so different, took Nahua practices and mentalities and made them its own. Third, we focus on two kinds of slavery: encomienda servitude based on money, debt, and tribute, and chattel slavery based on the notion of private property. The second variety based on nature falls into Mörner's caste category. It is a prominent strand that Anthony Pagden scrutinizes based on the Aristotelian model of natural slavery that Arab intelligentsia had recovered and restored in the West early in the second millennium making it available to be imposed on Abya Yala during the socalled Age of Discovery. ${ }^{27}$ We will investigate how Christopher Columbus, Thomas More, Erasmus of Rotterdam, and Bartolomé de las Casas all chiseled away at the Aristotelian concept of natural slavery with social templates thereby permuting what had initially been a caste system for Amerindians into a class system. For Latin Americans descended from Africans, however, few escaped at first from the caste system, and they oftentimes ended up in the estate system. Fewer yet moved into the class system thereby winning the potential for freedom.

\section{Coloniality of Structure and Coloniality of Mind}

One would not take or hold a person as a slave if one is not predisposed to do so mentally. As discussed in the introduction, that mentality formed psychologically or prejudicially. Here our task is not to study the differences between what is conscious and what is subconscious, for that is the task of cognitive psychologists. Indeed, few colonial subjects were truly conscious of what was going on and among them can be found the four primary subjects of our book. Before getting to them, our preliminary task requires considering coloniality of institutional structure and coloniality of mind in transatlantic formulations and in situations given form within nations.

Before we can get to the conditions of slavery and analogous forms of social subordination, the topic of this chapter, we must find their root underpinning, the coloniality of the mind. Colonialism leaves in its aftermath a footprint, an insidious condition best described as coloniality, difficult to perceive and even more to reverse. Nelson Maldonado-Torres puts it this way:

Coloniality is different from colonialism. Colonialism denotes a political and economic relation in which the sovereignty of a nation or a people rests on the power of another

26 Turner, Barbarous Mexico, 8.

27 On natural slavery, see Pagden, The Fall, especially chapter 3, "The Theory of Natural Slavery," 27-56. 
nation, which makes such nation an empire. Coloniality, instead, refers to long-standing patterns of power that emerged as a result of colonialism, but that define culture, labor, intersubjective relations, and knowledge production well beyond the strict limits of colonial administrations. ${ }^{28}$

Peruvian theorist Aníbal Quijano explains that coloniality is born in colonialism, which occurs when one country conquers the political and economic systems of another country. ${ }^{29} \mathrm{He}$ associates it with both capitalism and racism and affirms that it organizes daily life in both physical and subjective ways. For him, colonialism can be ephemeral, but coloniality is long lasting. ${ }^{30}$ John Chasteen brings us back to the hegemonic aspect of what we are calling coloniality as it flourished in Latin America. He explains it as "a kind of domination that implies a measure of consent by those at the bottom." ${ }^{31}$ Finally, to paraphrase and adapt an expression Mark Rifkin used to subtitle one of his books on US literature, we can talk about an "everyday coloniality" that permeated early modern quotidian activities occurring under empire and the attitudes that guided them as they were carried out. ${ }^{32}$

On top of that, we can consider a frequently unnoticed latter-day coloniality that limits our scholarly ability to study coloniality in earlier societies. One example can serve to clarify. Pagden, despite his recognition that "the Mexica and the Inca 'empires' were recognizable polities," affirms "the societies of the Mexica and the Inca were in many respects Neolithic ones." ${ }^{33}$ Neolithic? Neolithic, Webster's Unabridged Dictionary tells us, refers to the last phase of the Stone Age. It tells us that the Neolithic represents "the beginning of settled village life." ${ }^{34}$ By the time the Spanish had arrived, the Inkakuna were known for their great architectural achievements: palaces, temples, and plazas, which combined stone and metallurgical wonders all connected with a great system of roads and water distribution. While they had not yet found a use for the wheel (they did have disks in their religious artwork), they had an agricultural system that delivered a diverse selection of crops depending on the step platforms of rising altitudes. Furthermore, they had the knowledge to freeze-dry their food. While we should not blame Pagden for using the only word he knew, the universal application of a term that ascribes European history to other geographic areas, we can recognize that such a usage distorts those

28 Maldonado-Torres, “On the Coloniality of Being," 243.

29 Quijano, “Colonialidad del poder," 381n1.

30 Quijano, “Colonialidad del poder," 342. Besides Quijano, my understanding of coloniality as a mindset derives from my readings of Mignolo, The Darker Side of the Renaissance; and Ngũugĩ wa Thong'o, Decolonising the Mind. Recently, Mignolo has realized that coloniality does not need to originate as part of imperialism. He concludes, "There is coloniality without colonialism; for example, China or Japan or Russia. These formations were never colonized but did not escape coloniality" (Gaztambide-Fernández, “Decolonial Options," 197).

3 I Chasteen, Born in Blood and Fire, 57.

32 Rifkin, Settler Common Sense.

33 Pagden, The Fall, 58-59.

34 "Neolithic," Merriam-Webster's Unabridged Dictionary. http://unabridged.merriam-webster. com/unabridged/neolithic. Accessed February 2, 2019. 
realities outside of Europe and fosters a coloniality of interpretation. The temporalhistorical term in the Andes for the Inkan period is Late Horizon, the Mesoamerican one for the Mexicatl period is Postclassic. Late Horizon and Postclassic are more neutral for Inkakuna and Mexica than Neolithic and are helpful terms in fostering decoloniality. When Europeans and North Americans attach terms and labels derived from European realities to non-European people, they distort those people and their style of life. ${ }^{35}$ This is the challenging task for scholars and students in our time, to overcome the coloniality that can cloud research methods and the attitudes that give them form.

Essential to decoding the system of gears and cogs that serve as the locomotion for everyday coloniality in its "transhistoric" unfolding across time is recognizing that the past forms the present. As Moraña, Dussel, and Jáuregui conclude, "the Latin American modern subject is the product of a traumatic origin." ${ }^{36}$ This is true, firstly, because people who originated in Abya Yala and Africa were subordinated with cruel and ruthless methods and secondly, because mestizos and later Criollos were subordinated to Peninsulares. After Independence, Criollos copied their Spanish masters and then developed even more sophisticated methods they then hoisted upon people of African and Indigenous origins. This then constitutes internal or intra colonialism. The past becomes the present, which is not quantifiable without considering the elements that gave form to the past and thereby giving form to coloniality.

Since the lands that became American countries were "discovered" during the Spanish Renaissance, an argument can be made to focus on that time and place to "discover" the origins of coloniality. Consider the Spanish invasion of the Indies, a story whose basic outlines are well known from primary and secondary school textbooks. Lesser known is how coloniality functioned during that time as it shaped those events. One of Bartolomé de las Casas's experiences is illustrative: After his religious conversion, he returned to Spain to argue for the abolition of West Indian slavery. The year was 1515 and King Ferdinand, in poor health, was en route to Seville and its warmer clime. In Placencia, on Christmas Eve, Las Casas had the opportunity to "inform" the Catholic sovereign, who suggested that he come to Seville during Easter for a longer audience.

The first roadblock to changing the king's mind regarding Amerindian slaves was the king himself. Paul Vickery sets the record straight: "King Ferdinand was the largest holder of Indians." ${ }^{37}$ According to Pagden, the king seems to have based his right to hold slaves, and perhaps the right for Spaniards in general to practice slavery, on the papal bull, Eximie devotionis. ${ }^{38}$ The pope of course was a strong font of authority for the crown.

35 On coloniality restricting objectivity in what should be postcolonial scholarship, see Ward, Decolonizing Indigeneity, xi-xxiv, 1-33.

36 Moraña, Dussel, and Jáuregui, “Colonialism and its Replicants," 2.

37 Vickery, Bartolomé de las Casas, 70.

38 Pagden, The Fall, 29. Later, Pagden fills out the complicated reality when he affirms, "the Castilian crown, had never, in fact, been entirely certain about its right to enslave Indians," The Fall, 31. He recounts a meeting in Burgos where the licentiate and the future bishop of Cuba, Gill Gregorio, considered the Indigenous barbarians and thus slaves. The lawyer Juan López de Palacios Rubios, however, noted the Indigenous were rational and therefore preserved the right to "freedom 
But so was the pull of money. The essential roadblock to overcoming the coloniality of mind that accepted slavery resided with the aging and infirm monarch. Yet, that was not the only one. To get to a sovereign who liked to delegate matters pertaining to the Indies, Las Casas had to go through the supremely powerful bishop of Burgos, Juan Rodríguez de Fonseca, and the royal secretary, Lope Conchillos, who would eventually become president of the Secretaría de Indias. Both officials, by Las Casas's account, "had Indians and so many ..." (tenían indios, y tantos ...). ${ }^{39}$ Neither of them had any inclination to let Las Casas talk to the aging monarch because it would go against their financial interests. Marcel Brion wrote nine decades ago about Fernand's court and its reaction to Las Casas's appearance there: "quickly informed of his arrival, it immediately set about to bar all routes." ${ }^{40}$ The minds of the powerful men at the court just as much as the king's mind concocted the obstacles Las Casas had to confront.

Then, unfortunately for millions of West Indian people, the king passed away on January 16, 1516, before the Easter audience he was to have had with the Dominican friar. The series of ordinances known as Leyes de Burgos (1512) that allowed for encomienda slavery would stand. ${ }^{41}$ That system was so totally encompassing that historian Keith argues it "dominated Peruvian life completely," much like the hacienda that followed it and not so unlike the European fief with which it held much in common. ${ }^{42}$ Pagden observes that with massive expansion after grabbing a hold on Peru in 1532 so many more people came into the king's dominions. He states starkly, "With a far greater number of Indians to abuse and greater prizes to be won, the colonists' excesses grew." ${ }^{43}$ We will get to the details of how encomienda slavery worked later in this chapter. For now, we continue to focus on Las Casas and this condition we call coloniality.

There are other revealing episodes involving Las Casas. In the middle of the controversy surrounding his attempts to evangelize the K'ekchi' or Achi people with the book rather than the sword in what is today the Guatemalan departments of Upper and Lower Vera Paz, the Spanish council of Santiago, Guatemala, sent a letter to the king describing Las Casas as an illiterate friar who was passionate but envious, turbulent, and not saintly. ${ }^{44}$ They ratcheted up the tone when they added that all the king's dominions were

and independence," The Fall, 47-52. In 1513 Palacios Rubios authored the Requerimiento, a document written in Spanish that Spaniards read to Indigenous people (who of course did not speak Spanish) demanding that they accept the authority of the king of Spain.

39 Las Casas, Historia de las Indias, vol. 3, chap. 84, p. 299.

40 Brion, Bartolomé de las Casas, 68.

4I On the Leyes de Burges allowing the encomenderos to "enjoy" West Indian peoples, see Altamira, "El texto de las Leyes de Burgos de 1512," ley 1, p. 26.

42 Keith, Conquest and Agrarian Change, 28, 29.

43 Pagden, The Fall, 59.

44 K'ekchi' has many spelling variants, among them Q'eqchi' and Kekchí. Among the many sources on Las Casas's efforts in Vera Paz is Abellán, "La experiencia," Bataillon, "La Vera Paz," and Arias, Retórica, 78-84. 
in revolt, and that if the king did not take measures, all would be lost. ${ }^{45}$ While defaming someone to protect ill-gotten wealth certainly suggests an oral or written manifestation of coloniality, the actions of speaking or writing themselves respond to an idea that resides in the mind. The bureaucrats of the court and the council members of Santiago would not have contested Las Casas's efforts if it were not for the ideas, conceptions, interests, fears, and prejudices they held in their minds. Stated differently, the unnoticed and thus unquestioned coloniality of the Weltanschauung of that time informed how they themselves saw the world.

Another way to illustrate coloniality of mind from the perspective of the powerful is through the mindset pervading the invading forces, the one which, as Restall remarks, held that "native peoples were Spanish subjects waiting to be located and informed of their new status." It does not matter that "native peoples" had not heard of Spaniards before. These invaders immediately expected them to behave as if they understood themselves as subjects of the Spanish crown and that they were ex post facto integrated into the mindset and social structure being imposed. Additionally, as Restall puts it, there was "an assumption of rightful acquisition." When native peoples did not fathom that assumption, Spaniards could initiate a just war. In this context, "Spanish military activities were then framed as campaigns of 'pacification' rather than conquest, and resistance leaders could be tried and executed for treason." ${ }^{46}$ The subordinating manner of thinking was one side of coloniality of mind, and when Amerindians began to buy into it, the other side, they accepted their own inferiority. This buying into it is exactly Chasteen's concept of hegemony at work. Walter Mignolo describes the relationship between the social and intellectual forces as "an imperial management of human subjectivities." ${ }^{47}$ As the years turned to decades these two sides of the coloniality of mind were passed down to the descendants of "Indians," Spaniards, and Africans. People would have to know their place or be very astute and figure out how to outmaneuver the coloniality that defined their place.

The human tendency for acquisitiveness as seen with King Ferdinand, Bishop Rodríguez de Fonseca, Royal Secretary Lope Conchillos, members of the Spanish council of Santiago, and all the conquistadors/now encomenderos leads to a defense of imperialist policies. We recognize from the social sciences what Wang, Seidler, Hall, and Preston underscore: "Acquisitiveness is widely regarded as a fundamental human trait." ${ }^{48}$ Acquisitiveness can be detected in humans because they desire status, wealth, or simply the appearance of wealth. ${ }^{49}$ Peter Klarén writing about encomenderos in Peru explains that they "spent lavishly on conspicuous consumption, not only to validate their aspirations for aristocratic lifestyles and status but to display their 'power' as grandees

45 Hanke, “Introducción,” 51.

46 Restall, Seven Myths, 68.

47 Mignolo, "Racism as we Sense it Today," 1740.

48 Wang, Seidler, Hall, and Preston, "The Neural Bases of Acquisitiveness," 944.

49 Preston, "Toward an Interdisciplinary Science of Consumption," 2, 9. 
in the colonial society." ${ }^{50}$ There was the corresponding factor of greed (examined more fully in chapter 3). And, certainly under the oftentimes hypocritical veneer of a concern for the souls of Indigenous people, there was the unvarnished primary thrust Alex Dupuy describes in stark terms: "The greed for the precious metals was the primary reason for the colonization of the Greater Antilles."51 Dupuy's assertion is not only valid for the Caribbean but also for Central Mexico, Peru, the Amazon Basin, the US Southwest, the Southern Cone, and other places. Slaves and cheap labor were the easiest way to gather precious metals. It would go against the human nature of most individuals who are in the process of getting rich to support legislation that would remove their acquisitions from them, even when those acquisitions were people.

This brings back to mind to the 1515 episode with Las Casas and Lope Conchillos who now held in encomienda the Puerto Rican Chief Jamaica Arecibo and 200 of his Taíno subjects, some classified as naboría, a word from that language meaning "service Indian." Seduced by money and wealth, why would secretary Conchillos even consider the possibility of freeing his naborías? Unsurprisingly, he was not inclined toward the idea of liberating them. In fact, in Vickery's take on his meeting with Las Casas, "Conchillos promised to give him whatever he deserved in the Indies." ${ }^{52}$ In other words, he promised Las Casas immense riches in exchange for his silence. The Dominican, perhaps to Conchillos's surprise, rebuffed the offer, essentially a bribe. It takes an exceptional man or women to give up prosperity and opulence in the name of justice, ethics, spiritual concerns, or humanity itself. Las Casas, to be sure, became one of the few early Spaniards to overcome the seduction of imperialism's monetary benefits. The Crown did not abolish the encomienda until 1542, and then only did so in favor of mercantilist structures of subordination that shifted economic power from the encomendero. Secretary Conchillos supported a coloniality of structure in the government because he suffered from greed and a desire for wealth and status, attributes of coloniality in his mind even though he lived in Spain. This coloniality of mind provoked in him the conditions to mold even more people into a coloniality of mind, because they too desired wealth and status. Subsequently, they folded yet others into the mindset and system of coloniality.

As derived from Gramsci and Chasteen's description of hegemony, coloniality also resides in the mind of the colonized. Anand Pranjpe, although writing on the Indian Subcontinent, expressed a situation applicable to the Amerindians: "colonised people often attribute their defeat to the inferiority of their ancestral culture, or to native conceptions of knowledge." ${ }^{53}$ Peruvian theorist Antonio Cornejo Polar defines coloniality of mind as a kind of private coloniality that victims of imperialism store away outside of the public sphere. He describes it as "a power capable of reproducing itself even in the most private instants of colonial life, even in dreams, imagination and desires" (un poder

50 Klarén, Peru, 47.

5 I Dupuy, "Spanish Colonialism and the Origin of Underdevelopment in Haiti," 15.

52 Vickery, Bartolomé de las Casas, 71.

53 Pranjpe, "Indigenous Psychology," 28. 
capaz de reproducirse inclusive en las instancias más privadas de la vida colonial, hasta en los sueños, la imaginación y los deseos). These dreams and desires are constrained by the physical barriers of coloniality with which the mind comes in contact, and which then became the metaphors for the psychological barriers. In some minds, doubtlessly there are contradictions. Cornejo Polar continues: "almost submerged, gestures, attitudes, and movements of resistance also are dispersed through the entire social body and through its most subtle fissures" (casi subterráneamente, gestos, actitudes y movimientos de resistencia que también se despliegan por todo el cuerpos social, y por sus más sutiles intersticios).$^{54}$ Thus, coloniality or resistance to it is not always apparent to the eye or to the historian who would reveal it.

Mignolo outlines four avenues through which everyday coloniality can be imbedded: the economic, the political, and the civic are physical templates, the fourth, the subjective, is an epistemic template. By the economic, he means the "appropriation of land, exploitation of labor, and control of finance." In the English territories land was what most mattered, although, the Spanish did immediately set about seizing lands for the cities they were founding such as Vera Cruz at the Mexican beachhead. However, as Patricia Seed notes in her well-researched American Pentimento, the Spanish were initially and primarily concerned with encomienda labor, not land, and with chattel slavery. With respect to the affinity for this latter model of servitude, the Spanish were not so unlike the English. They both put a monetary value on people in Africa and other places and then engaged in trade in those peoples. Since the wealthy tended not to pay taxes, a contribución de indios burdened Amerindian peoples held in encomienda or later in hacienda, though not people of African heritage, because they were held as property. This is true because, while the conquistadors and their successors, the encomenderos, had to pay the royal fifth, they paid for it by extracting more wealth from the people they were conquering. In Paraguay, though, Spaniards did have to pay a head tax on each "Indian" they enslaved until Indigenous slavery was outlawed. In later colonial times, Peninsulares and Criollos alike were mostly exempted from taxation since the indios endeudados held that burden. ${ }^{55}$ Incontrovertibly, as Mario Pastore remarks, the encomienda was viewed as a vehicle for "tax farming." ${ }^{56}$ While Andean people were reduced to tributarios, people of African ancestry were treated far worse as chattel, or property.

Regarding the political, "the control of authority" as a means of imbedding tangible coloniality requires considering military, legal, and governmental arrangements that subordinated homologous structures in transatlantic regions. Viceregal courts regulated and reorganized conquered subjects, mercenary armies conquered outlying areas; audiencias competed in power and authority with the viceroy and supervised the hordes of letrados, or lawyers, who enticed colonial subjects, the victims of imperialism, to sue each other to derive substantial profit from those lawsuits undertaken. It was in this realm legal culture was born, and with it the letrados, at least in the Spanish-language

54 Cornejo Polar, "Los discursos coloniales," 216.

55 Pastore, “Taxation, Coercion, Trade and Development," 340.

56 Pastore, "Taxation, Coercion, Trade and Development," 343. 
field. As stated in the Introduction, Mignolo has noted that the letrados eventually accumulated more power than the humanists. This, of course, made liberation even more elusive.

To Mignolo's political we must add the religious, which, when used in conjunction with the political, as was typical during the early modern period, served as a mechanism of social control. The most common instruments to impose coloniality by religious means were the Extirpación de idolatría campaigns that tried (and sometimes succeeded in) reorganizing Mesoamerican and Andean spiritual beliefs. The other was its sister organ, the Inquisition, whose two most infamous fora resided in Lima and Mexico and which derived wealth by appropriating it from conversos (read people of Jewish heritage), chattel slaves, and even letrados and other individuals of Spanish stock. Sometimes, such as what happened with Hernán Cortés's advance into central Mexico, religious objects of veneration were simply smashed, suggesting unambiguously to local people their deities were inferior.

As for the civic, Mignolo mentions gender issues, which become problematized when conjoined to ethnicity, class, and the law, all of which mutually interact, in varying degrees, as configurations of control. ${ }^{57}$ We will explore the law below. As revealed in The Formation of Latin American Nations' chapter 4, gender and nation were (are!) seamlessly integrated. The early-dynastic Mexicatl rulers, for example, intermarried with women of other ethnicities when it suited their quest to accumulate power and prestige; this they did as they transcultured into the cultural ideal of Toltecayotl, or Toltecness, thereby climbing to the pinnacle of power elites in the Valley of Mexico. ${ }^{58}$ The female body, like the male body, as archaeologists John Papadopoulos and Gary Urton note in the introduction to their edited collection of essays by noted scholars on value, "may be commodified and objectified as labor, material, or art, or for sexual pleasure." 59 The female body can serve as a conduit for the transference of wealth. After their arrival on the scene, the Spanish bought into this system of using Amerindian women to gain wealth. ${ }^{60}$

Certainly, one essential difference between fourteenth-century late antiquity and sixteenth-century early modernity resides in the concept of nation. ${ }^{61}$ As James Lockhart's research shows, Nahua groups each lived in an altepetl, a kind of ethnic state. ${ }^{62}$ The Nahua's nation-building tactic of giving and taking women from different altepeme, but from the same Mesoamerican cultural complex as their own to benefit each individual

\section{Mignolo, The Idea of Latin America, 11.}

58 On Toltecayotl, Mignolo quotes and discusses León-Portilla in The Darker Side of the Renaissance, 141. For further discussion, see Ward, The Formation of Latin American Nations, 58-59, 69-72, 90-91.

59 Papadopoulous and Urton, "Introduction," 26.

60 Discussed in Ward, The Formation of Latin American Nations, chap. 4.

6I On the terms late antiquity and early modern and their relationship to the colonial era, Ward, The Formation of Latin American Nations, 3-5.

62 Lockhart, The Nahuas After the Conquest, 14. 
altepetl, differs from Spaniards' tactic of receiving (taking) women from a decidedly different culture for their own personal financial gain and their sexual desires. The Spanish taking was different from the intra-Nahua exchanges because such receiving benefited only the Spanish nation not the Nahua nations, called altepeme, where the benefit would have generally been mutual. Because Spaniards took women from a cultural complex different from their own, and because they subordinated members of that complex, the practice becomes what today's society calls racism. Because many of those subordinated people were women, what we would call sexism organizes the racial scaffolding. Peruvian historian Nelson Manrique recognizes this double jeopardy when he asserts, "In the intersection between racism and gender discrimination, women have inevitably become war booty for the war's victors" (En la intersección entre racismo y la discriminación de género la mujer ha sido invariablemente un botín de guerra para los vencedores) ${ }^{63}$ Inversely we can project that when women from a different cultural complex become war booty, a situation is systematized in terms of racism and sexism. We can certainly be referring to the long wars of Conquest, which in Peru were comprised by the Forty-Years War.

One useful way to look at this long, drawn out conflict is as Edmundo Guillén Guillén does. He calls it La guerra de reconquista inka which ran from 1536 to 1572. However, that focus and nomenclature does not adequately encompass the various civil wars among Andean ethic groups such as the one occurring in the so-called Siege of Lima between Inkakuna and Waylakuna (Huaylas in Spanish) (1536), between the Inka panakakuna of Waskar and Atawallpa (1527-1532), and the Spanish civil wars ending in 1541. We can understand the Taki Unquy, begun in 1564, as another kind of resistance to the Spanish presence. The Forty-Years War concluded with the execution in 1572 of Thupaq Amaru I, the last in a long line of Sapa Inka monarchs. The term "Forty-Years War" includes in its meaning all these bellicose facets. Alternatively, we can be talking about the soft wars that went on through the ages, interpersonal conflicts, in gendered and ethnic relationships (sometimes violent ones) even today. All of these-gender, class, and ethnic subordination-represent angles to institute and institutionalize hegemonic relationships.

Ultimately, we must recognize violence as part of "the civic," for it was perpetrated by the crown, the viceroy, the mercenaries, and even the clergy. Ricardo Salvatore expounds on this reality,

colonisation necessitated the perpetration of violence on the subjugated indigenous populations - a violence that was at first overwhelming but declined afterward-in order to produce subordination to Spanish authorities, some degree of conformity and deference to colonial officials, a transformation of everyday practices among the colonised, and a radical change in their religious beliefs. ${ }^{64}$

Spaniards in "the Province and Kingdom of Guatemala," Las Casas reports in his Brevísima relación de la destrucción de las Indias, threw people into holes, burned them alive, and

63 Manrique, La piel y la pluma, 14.

64 Salvatore, “Conclusion," 243. 
cut them into pieces. ${ }^{65}$ The ongoing brutal violence of the Conquest implies an ongoing and blatant disregard for human dignity during the sixteenth century.

Coloniality in this sense is broader and deeper than the material conditions that a conquering power might inflict on another nation. It is that, but it is much more. If we think about it, we can see tyrants imposed conditions internally on their own subjects during the period by means of mechanisms internal to the nation too. Castilians inflicted what we are calling coloniality within Spain on Moors, Jews, and Gypsies, as well as on Catalans, Basques, and Galicians. The everyday coloniality that occurs inside one country often takes on religious, racial, ethnic, or simply class overtones.

We can find it depicted in a canonical piece of European literature from just a century ago that shows that it can happen in one country or region to people living in that country or region. The Czech-Jewish author Franz Kafka's 1925 German-language novel The Trial illustrates clearly how the mechanisms of internal colonialism can function for an outsider, even in a non-imperial, but hegemonic, internal national situation. The way the novel depicts the legal system stands as a metaphor for how the law may have seemed to outsiders. Read metaphorically, it helps us to apprehend how it may have been for Amerindians listening to the Spanish-language Requerimiento pronouncement of submission or other types of legal documents or for recently captured Africans who did not fathom the language, the culture, the monetary system, or the substance of "The Law." A lack of familiarity with the legal system described in another language would be baffling to anyone subjected to it. Kafka's protagonist Joseph K. is a man whose absence of a last name suggests he is Everyman. He finds himself entrapped in a legal web from which there is no exit, notwithstanding his uncle's influence, his attorney's counsel, or even his own information-gathering attempts. The entire novel is concerned with his not understanding, his trying to understand, and finally his acceptance that he will never understand.

Kafka's novel could simply be a condemnation of legal systems in the West or even a condemnation of legal systems throughout humanity. Of the infinite possible readings of the novel, another could consider that Joseph $\mathrm{K}$. is a Czech Jew ensnarled in the Germanic legal system becoming bewildered as he considers his situation. When Joseph K. accepts his subordination to "The Law," that subordination is predicated on what we are describing as hegemony. Another of the infinite possible readings of the novel, one never intended by Kafka, but possible nevertheless, could be to read it a metaphor exemplifying the legal never-never-land plight of the original Americans, the first slaves, the first encomienda Indians, the first debt peons, and so forth, and the ignorance foisted upon them. What Kafka's protagonist Joseph K. went through in a system he could not understand, is not unlike what the Indigenous experienced when they had to go up against the legal system of the Spanish empire.

This is not so far-fetched for the twentieth century, but it is especially not so farfetched for the sixteenth century when transatlantic imperialism established the original mechanisms for transatlantic hegemony. Those mechanisms continue to survive. Writing

65 Las Casas, Tratados, 1:83-93. 
about twentieth-century Peru, anthropologist Enrique Mayer analyzes the situation that arose with events in a small town, Uchuraccay, in the province of Huanta, Ayacucho Department. In 1983, the Peruvian press had reported that a small group of peasants in the town had killed some combatants from the Sendero Luminoso revolutionary movement. A group of eight reporters and photographers from Lima and Ayacucho went to the town to investigate what had transpired there. Mysteriously all eight of them were killed too and the blame fell on the villagers. Some of the villagers were then murdered extrajudicially by elements of the state, others by additional Sendero Luminoso forces, and others fled to the Amazon or to Lima. Three of the villagers were put on trial. The Qheswa-speaking Simeón Aucatoma, Dionisio Morales, and Mario Ccasani appeared before a Spanish-speaking court. Because they did not understand Spanish, Mayer concludes, "The accused comuneros never even understood the court proceedings." 66 Mayer describes the villagers as coming from Deep Peru, a term developed by historian Jorge Basadre, popularized by the novelist José María Arguedas, and employed in a commission report about the massacre penned by the famous novelist Mario Vargas Llosa. Mayer explains that for the famous novelist, Deep Peru is Indigenous Peru. ${ }^{67}$ For Mayer, "Deep Peru includes Kafkian judicial systems, which it calls its administration of justice, that systematically enmesh lower-class and Quechua-speaking citizens in complicated and unreal proceedings." ${ }^{68}$ The experience of those villagers thrust into the Hispanic legal system were not unlike Joseph K.'s experience in The Trial, nor would it have been much different from what Qheswa-speaking people in earlier centuries experienced who were also subjected to a system, be it the Audiencia, the Extirpation of Idols campaigns, or the Inquisition, that were also conducted in the Spanish language.

The same kinds of legal conditions inspired another great writer, Thomas More, to free the citizens of his Utopia from The Law. We are told regarding the Utopians:

they absolutely banish from their country all lawyers, who cleverly manipulate cases and cunningly argue legal points. They consider it a good thing that every man should plead his own cause and say the same to the judge as he would tell his counsel.

Anyone "uncoached in deception by a lawyer" ${ }^{69}$ can present the unvarnished facts in a court of law so that the judge can make a decision based on the unadulterated truth. More has his Utopians spurn lawyers so that they can overcome the disadvantages of a Europe overburdened by a hodgepodge of complex laws. Such laws, given that lawyers will forever be clever and cunning, tend to favor the people who can afford such counsel and disadvantage those who cannot. This disparity between the favored and the disfavored in a legal system could be taken as another form of coloniality.

Mignolo's fourth category, the epistemic, the most difficult to quantify given the loss of documentation, resides in "the subjective/personal control of knowledge and subjectivity." This is the kernel of coloniality of mind, when thought itself is shaped by

66 Mayer, "Peru in Deep Trouble," 491. I also consulted Vargas Llosa, "The Story of a Massacre."

67 Mayer, "Peru in Deep Trouble," 477-78.

68 Mayer, "Peru in Deep Trouble," 484.

69 More, Yale Edition, 4:194-95. 
exigencies of imperialism. This fourth channel, what he labels the "colonial matrix," "is invisible to distracted eyes, and even when it surfaces, it is explained through the rhetoric of modernity that the situation can be 'corrected' with 'development.' "70 It is this stealthy quality of coloniality that makes it insidious because, if invisible, there is no way to correct it, except to begin to try to make it visible. By acute observation, as we will see with Thomas More, Erasmus, Las Casas, and Guaman Poma de Ayala, the matrix's mechanisms can be revealed.

There are two sides to the coloniality of mind that may or may not be palpable in the physical world: (1) the oppressor's greed fed by feelings of superiority and entitlement, and (2) the oppressed' feelings of inadequacy that debilitates the mind. Regarding the later, Mignolo draws on the work of Frantz Fanon to come to the following conclusion: "Perspectives from coloniality ... emerge out of the conditions of the 'colonial wound,' the feeling of inferiority imposed on human beings who do not fit the predetermined model in Euro-American narratives." ${ }^{11}$ Regarding the Andean region, Manuel Burga draws on the work of Wachtel when he explains that the Inkakuna, after being defeated militarily, began to look into their traditions where they found "signs, omens and prophecies" (signos, presagios y profecías) that they began to reinterpret in an attempt to fathom "the reigning nobility's stupefaction and docility in the face of the European invaders" (la estupefacción y docilidad de las noblezas reinantes ante los invasores europeos)..$^{72}$ Hence, two sides to the coin of everyday coloniality are apparent: attitudes that inform imperialist mentalities and attitudes that inform the mentalities of the colonized. Only by addressing them, can we treat the "colonial wound."

\section{Nahua Slavery, Spanish Slavery, and Spanish Appropriation of Nahua Slavery}

One of the most obvious manifestations of coloniality thrives in the institution of slavery. Oftentimes we think of slavery as originating with Columbus and therefore having a 400year trajectory in the Americas that arises suddenly in 1492 when the Great Navigator scooped up several Caribbean people to bring back to the Spanish peninsula and ends with the abolition of that terrible institution. However, human bondage was not only customary in ancient and medieval European cultures, and in millenary African cultures, it similarly existed in Abya Yala long before the arrival of Columbus. ${ }^{73}$ Besides the naboría (the Caribbean), the mita (Peru), the coatequitl (Mexico), and pongo labor (Peru), there were other variants. Europeans quickly became aware of autochthonous practices of this nature.

Chroniclers document pre-Hispanic servitude in the Indies when Hernán Cortés (1485-1547) arrived in Tenochtitlan, the Mexicatl (imprecisely called Aztec) capital.

\footnotetext{
70 Mignolo, The Idea of Latin America, 11, xi.

$7 \mathrm{I}$ Mignolo, The Idea of Latin America, xii.

72 Burga, Nacimiento, 167.

73 Moreno Toscano, "La esclavitud," 343.
} 
As with European traditions later imposed, in Mesoamerica one altepetl, or etnia, tended to enslave members of another. "Etnia" is used here in the sense Anthony Smith assigned to it, "ethnic community," which is the way it is used in Spanish or French. ${ }^{74}$ Spaniards such as Bernal Díaz del Castillo (1495-1584) did not use such terminology. Neither did they turn to more commonly used terms such as nación because such a choice would move them toward recognizing Indigenous nations as bona fide entities. Thus, Spaniards tended to employ a generically and erroneously constructed term, "Indians," because it made the different etnias seem less than civil societies. Even so, in late antiquity Abya Yala, state-sponsored interethnic slavery existed. In the Guatemala manuscript of his Historia verdadera de la conquista de la Nueva España, Díaz del Castillo observes, "the Indians and chiefs commonly held a quantity of men and women as slaves, and they sold and traded them as one would any type of merchandise" (los indios y çaciques comúnmente tenían cantidad de indios e indias por esclavos, y que los vendían y contratavan con ellos como se contrata cualquier mercaduría) $(H V, 669 a){ }^{75}$ Another chronicler of the first point of contact between the two cultures, Francisco López de Gómara, makes plain that thieves, families of traitors, men who were responsible for the pregnancy of female slaves, prostitutes, and even youngsters could become enslaved. ${ }^{76}$ The slave market was so lucrative that Fray Bernardino de Sahagún is able to affirm in his Historia general that the slaver was first and foremost of all the vendors. ${ }^{77}$ As discussed in The Formation of Latin American Nations, the Mexica's slaves often came from other etnias, such as from Cempoal or Tlaxcala. As documented in that book, frequently the interethnic slaves for nation-expanding goals were women. As map 1 shows, plenty of etnias lived around Tenochtitlan that could serve as sources of slaves.

Slavery seems to have been common in other areas of Mesoamerica too. The K'iche' may have been the most powerful collective among the various groups of Maya, an ethnonym not necessarily used by the diverse groups in that frequently employed, but artificially constructed, category (see map 2). In any case, they are emblematic for Mesoamerica. K'iche' documents such as the Popol Vuh, now spelt Popol Wuj, reveal the presence of precontact slavery in the lands today known as Guatemala. Before the K'iche' had emigrated from their original city of Izmachi, the Ilocab entered into war with them. The Popol Wuj recounts that the Ilocab were defeated, some sacrificed, while others "fell into slavery and in servitude" (cayeron en esclavitud y en servidumbre). After Balam Quitzé, Balam Acab, Mahucutah, and Iqui Balam, the founding fathers of the nation, left Izmachi and founded a new capital city, Q'umarkaj, spelt Gumarcaah in the text, the K'iche' found themselves the object of hostilities. This time, people such as

74 Smith, The Antiquity, 1. Smith uses the French variant ethnie; here we use, where possible, the Spanish form, etnia. No comparable term exists in English, except the bulky expression "ethnic group."

75 In this chapter, references to Díaz del Castillo’s Historia verdadera, Sáenz de Santa María edition, will be indicated parenthetically and abbreviated as $H V$.

76 López de Gómara, Historia de la conquista de México, 343-44.

77 Sahagún, General History, vol. 10, pt. 11, 59a. 


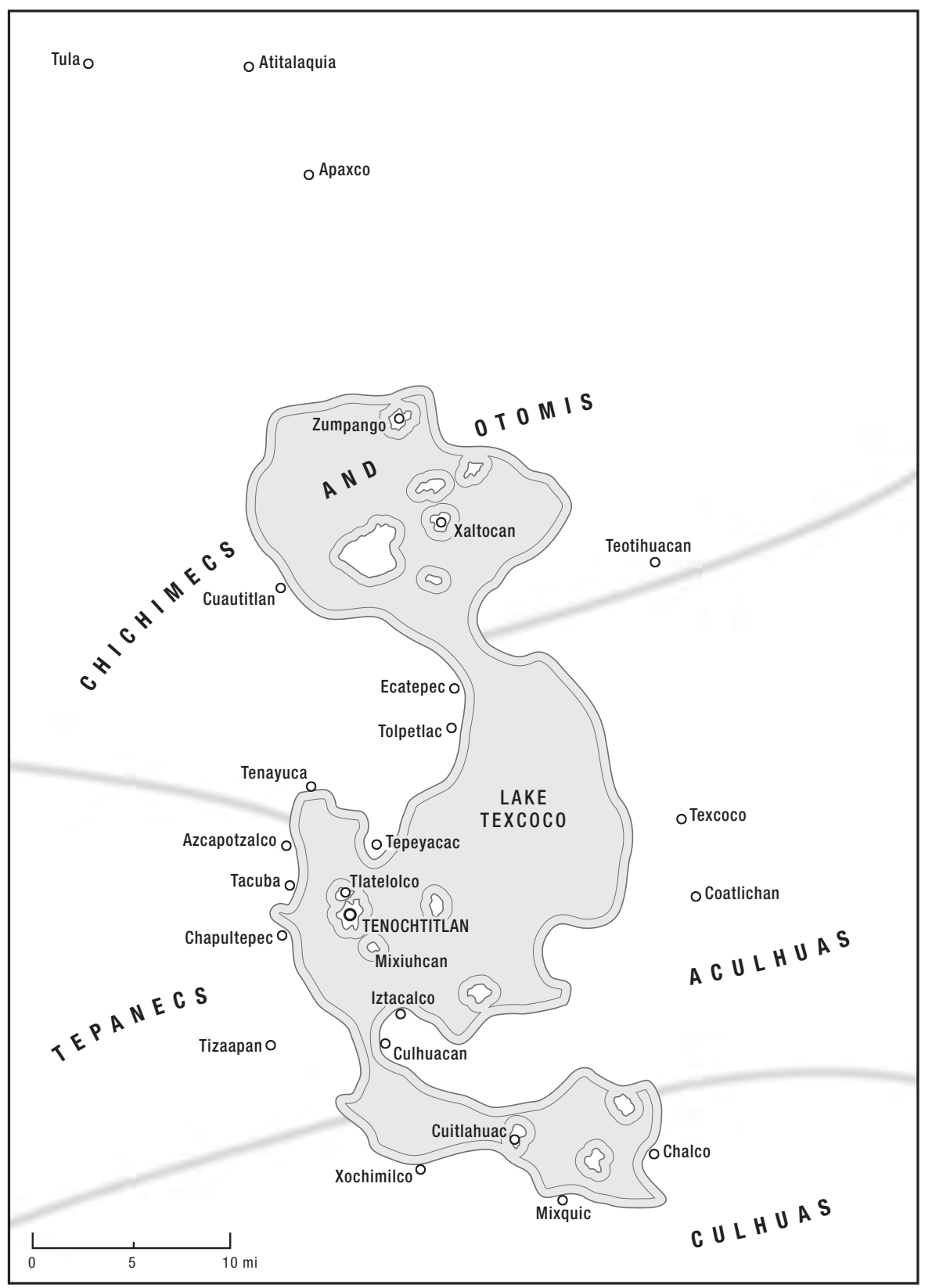

Map 1. Primary ethnic nations in Anahuac. From Nigel Davies, The Aztecs (Norman: University of Oklahoma Press, 1980), 19. Map by Erin Greb Cartography. 
the Kaqchikels and others waged war on them, but they were defeated and the K'iche' "made them slaves" (Los hicieron esclavos). Besides the Kaqchikels, the K'iche' enslaved people from the Rabinal and the Zaculeu nations. ${ }^{78}$ The making of the soldiers of defeated armies slaves is similar to Mexica policy, and as we will see, is not so far from situations in Europe as Thomas More outlines.

The pre-Hispanic Nahua likewise practiced human subordination to such a degree that their language, Nahuatl, had a noun, tlacanamacac, for the slave merchant, and a verb, tlacanamaca, to sell people. ${ }^{79}$ Slaves themselves were called tlatlacotin (sing. tlacotli). ${ }^{80}$ The institution of slavery was so ingrained in Nahua society that it appears in their mythology. Alfonso Caso highlights Xilonen, a young bondmaid carried on the shoulders of a priest. ${ }^{81}$ Clendinnen finds in her research that Nahua servitude could be a punishment for an offense, or simply a matter of contract. ${ }^{82}$ Frequently slaves came from other ethnic nations, such as from the Otomi, the Chichimeca, and the Totonaca. While we now discern several aspects of Nahua slavery, there is still much to learn. ${ }^{83}$ We do not know, for instance, if it had the blatant sexual overtones later apparent to Nahua informants during the battles of the Spanish invasion and Mexicatl resistance to them. Continued appraisal of Nahuatl philological evidence may provide further insight on this issue.

The most famous woman from the early colonial era, La Malinche, was twice given to a different etnia as a slave, first to a Mayan group, then to the Spanish group. Restall fixes her origins, "a Nahua noblewoman from the eastern edge of Nahuatlspeaking central Mexico." ${ }^{84}$ Bernal Díaz relates her story. ${ }^{85}$ Because she was an heir to the "throne," it became politically expedient for her birth family to get rid of her. Her mother's female servant happened to die, making it possible to substitute her for the bondswoman. Malinche's parents, Díaz del Castillo explains, "gave her to those from Tabasco" (la dieron a los de Tabasco) as a slave. The Tabascans later presented her to Cortés $(H V, 69 \mathrm{a})$. As a consequence of passing from one etnia to another, Cortés acquired a bilingual Malintzin, fluent in Yucatec or Chontal Maya and in Nahuatl. ${ }^{86}$ The

78 Popol Vuh, IV, vii, x, ed. Recinos, pp. 145, 151.

79 The remainder of this section draws from one section, "Nahua and Spanish Slavery," and part of another, "The Spanish Appropriation of Nahua Slavery," of a lengthy article published in the journal MLN. Ward, "Expanding Ethnicity," 435-39.

80 See Siméon, Diccionario, 558b, 578, 663a.

8 I Caso, El pueblo del sol, 65.

82 Clendinnen, Aztecs, 99-100.

83 See Gibson, The Aztecs, 153.

84 Restall, Seven Myths, 82.

85 For more on this, see Rose de Fuggle, "Bernal Díaz del Castillo cuentista."

86 Restall is one of the few commentators who specifies doña Marina spoke the Yucatec Mayan language and explains she had been given to the Chontal Maya. Restall, Seven Myths, 83, 84. 


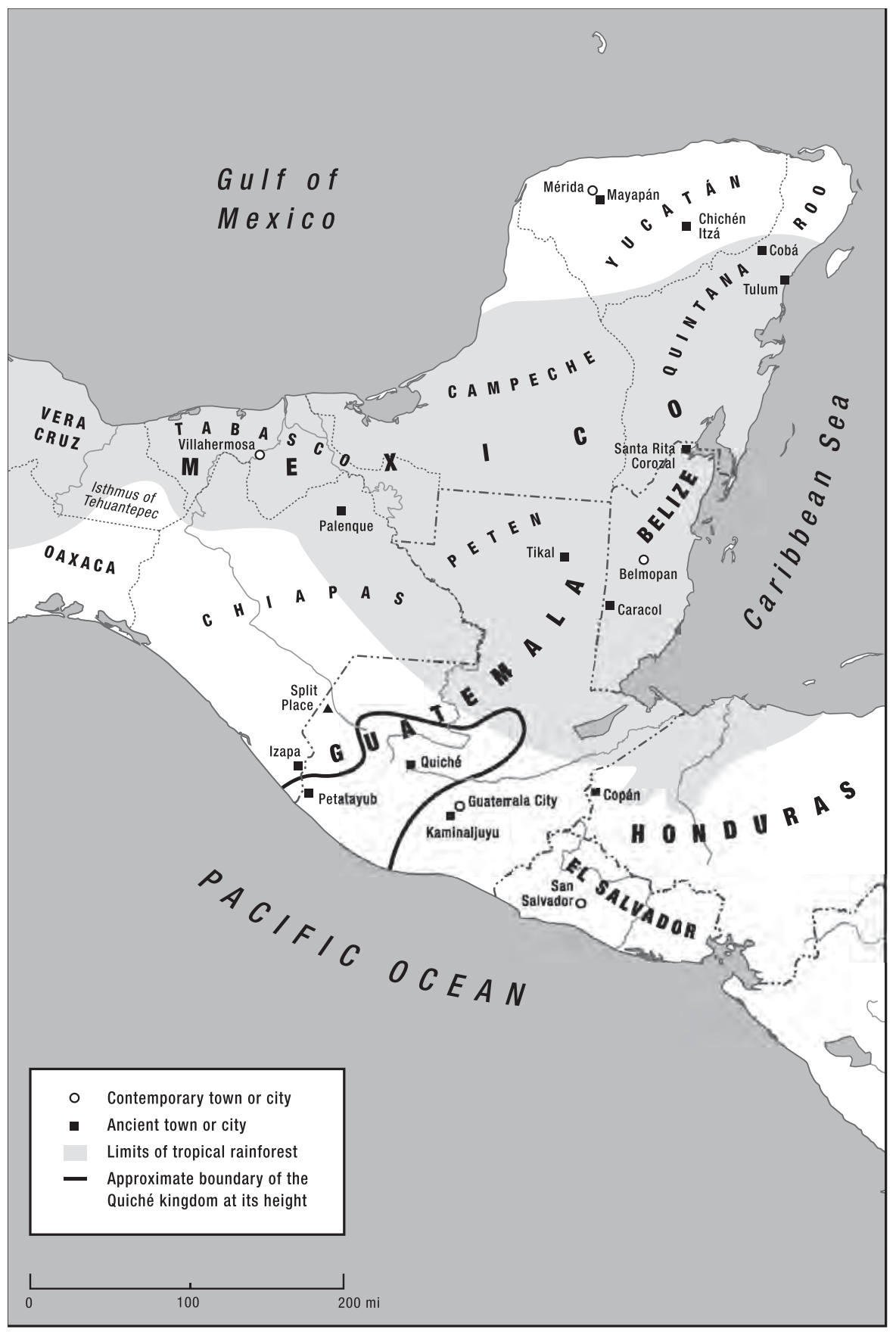

Map 2. The Mayan region. From POPOL VUH: The Definitive Edition of the Mayan Book of the Dawn of Life and the Glories of Gods and Kings, revised and expanded by Dennis Tedlock, translator. Copyright (C) 1985, 1996, p. 20. Reprinted with the permission of Touchstone, a division of Simon \& Schuster, Inc. All rights reserved. Map by Erin Greb Cartography. 
practice of interethnic bondage was not limited to women alone. Lockhart confirms the existence of child slaves who had "come from a distance." ${ }^{87}$ According to Díaz, the Mexica took Tlaxcalteca as slaves for over one hundred years $(H V, 129 \mathrm{a})$. These Mexica practices somewhat aligned with norms demanded by the Greek ideology that Aristotle exemplified during the sixteenth century: they both understood slavery as an interethnic convention. ${ }^{88}$ The essential difference was that the Mexica held no theory comparable to Aristotle's theory of natural slavery; nor did they compare the relationship between body and soul with that between master and slave. Bondsmen in Anahuac could own property and get married. ${ }^{89}$ Nahua servitude differed from European concepts in other ways.

Nahua slaves in the main came from outside their peer group (as in Aristotle), but they could elevate themselves to a higher status. Father Diego Durán narrates that Acamapichtli, the first Mexicatl tlatoani, had a female slave from Azcapotzalco, from a neighbourhood called Cualuhacalco. She was so beautiful the tlatoani became enamored of her. She then became pregnant, giving birth to a son, Itzcoatl. ${ }^{90}$ Although born out of wedlock and the son of a slave woman, Itzcoatl later became a "king" (1426-1440). How could this be? After Tepanecatl assassins murdered Acamapichtli's grandson Chimalpopoca, the "throne" reverted to Chimalpopoca's uncle, Itzcoatl, the son of Acamapichtli and his Tepanecatl slave. Such a succession would have been impossible according to the more rigid Renaissance conventions with their Aristotelian underpinnings. To the contrary, it was quite acceptable to the Mexica. It is ironic that Itzcoatl, the son of a bondswoman, would later make his name as the first independent-minded Mexicatl tlatoani, free from the control of both the Tepaneca and the Acolhuaque (sing. Acolhua). This historical fact similarly demonstrates the fluidity of Mexica notions of ethnicity.

To be sure, Spaniards engaged in bondage too. Their annexation of ethnic nations of Mexico began as a series of slaving missions. Francisco Hernández de Córdoba led the first Spanish voyage to Mexico. Its mission was explicitly to capture slaves for return to Cuba. Juan de Grijalva led the second Spanish voyage. Díaz del Castillo participated in those early missions before his third expedition with Hernán Cortés. ${ }^{91}$ Because Spaniards did not hold Spaniards or Christians in thrall, they favored other etnias for that purpose. ${ }^{92}$ We will deal with the Spanish/European philosophy of slavery as we proceed. Here we are establishing an overview on the practices.

87 Lockhart, The Nahuas After the Conquest, 99-100.

88 For a comprehensive treatment of Aristotle's application in Abya Yala, see Hanke, Aristotle and The Spanish Struggle; also Pagden, The Fall.

89 Cline, "The Spiritual Conquest," 463.

90 Durán, Historia de las Indias, 2:56.

9 I Ramírez Cabañas, “Introducción,” xi.

92 Regarding Christians not enslaving Christians, see Phillips and Phillips, "Spain in the Fifteenth Century," 20. 
Early on in the Historia verdadera, the reader runs into the European enslavement of people on the island of Cuba. In the "Guatemala" manuscript, Díaz del Castillo recounts how on two occasions the governor of Cuba Diego Velázquez promises him "Indians" as soon as some become available $(H V, 4 \mathrm{~b}, 5 \mathrm{a}, 5 \mathrm{~b})$. In both the "Guatemala" and the "Remón" manuscripts, the foot-soldier chronicler remembers one occasion when, to raise money for vessels to conquer the mainland, he and his cohorts had to go to war and fill the boats with "Indians" from the islands who could then be used to acquire funds. In this case, Díaz del Castillo explicitly uses the term slaves ( $H V, 5 \mathrm{a}, 5 \mathrm{~b})$. The foot-soldier chronicler narrates all this in a matter of fact way but in the face of the verifiable remorse at enslaving free people against the wishes of God and the King $(H V, 5 a, 5 b)$.

Human servitude as practiced by the Spanish was an economic tool. As Rolena Adorno so convincingly evinces, Díaz del Castillo's primary interests in the Spanish wars against native people were economic. ${ }^{93} \mathrm{He}$ did not hide these concerns. As stated, Díaz flat out admits practicing slavery. His testimony provides insight into the mindset of those years. He reveals that Velázquez promised slaves as remuneration for work: "he showed us much love and promised he would give us Indians" (nos mostró mucho amor y prometió que nos daría indios) $(\mathrm{HV}, 5 \mathrm{5}) .{ }^{94}$ In economic terms, enslaving people was justified "to pay for the boat with them" (para pagar con ellos el barco)..$^{95}$ He remembers that Hernández de Córdoba "had pueblos de indios on that island" (tenía pueblos de indios en aquella isla) $(\mathrm{HV}, 5 \mathrm{a}) .{ }^{96}$ Pueblos de indios were towns where Indigenous people were conjugated. They differed from Pueblos de españoles where Spaniards were zoned to live. That Hernández de Córdoba had pueblos de indios literally means that he had "towns" of "Indians" at his disposal. The key verb here is tener whose meaning has remained relatively constant over the centuries. In 1739 the Diccionario de la lengua española lists one of its meanings as "to possess, and enjoy" (posseer, y gozar) while in 1990 the Pequeño Larousse reads "to possess and enjoy something" (poseer y gozar una cosa). ${ }^{97}$ With "to have," and "to possess," there are connotations of property ownership. In this context, "to enjoy," signifies exploitation and even the commission of acts of violence. As we can suppose with the division between the pueblos de indios and the pueblos de españoles, a theoretical separation surfaces between the slavers and the slaves.

The crown sought to keep the conquerors legally separate from the conquered. The segregation of Spaniards and Amerindians into distinct pueblos was a way to favor one group over another. Robert Jackson articulates that

93 Adorno, "Discourses on Colonialism."

94 Variance in "Guatemala" manuscript: "me prometió" (HV, 4b); "nos prometió que nos daría indios" ( $H V, 5 b)$.

95 Variance in "Guatemala" manuscript: "para pagar con indios el barco, para servirse de ellos por esclavos" ( $H V, 5 \mathrm{~b})$.

96 Variance in "Guatemala" manuscript: "tenía pueblo de indios en aquella isla" ( $H V, 5 b)$.

97 "tener," Diccionario de la lengua castellana, t. 6; and Pequeño Larousse, 990b. 
Spain imposed sumptuary laws (laws prohibiting designated groups in society from consuming certain goods, such as luxury textiles) and created separate fiscal statuses and obligations and legal systems for the indigenous and nonindigenous populations. ${ }^{98}$

While on the surface all strata appeared legally isolated, in practice there was intense cross-cultural and cross-social osmosis. This occurred especially when both forms of society coincided. One aspect of Nahua civil society that overlapped with the Spanish way of life was the acceptance and practice of slavery.

Slavery was economically viable for imperial mining, and sugar and later cotton interests, because the work required was rudimentary. Wallerstein explains that slaves will only do what they are coerced to do and nothing more. Therefore, the slave masters could not depend on the slaves for more-detailed labor. ${ }^{99}$ Wallerstein is referring to what would be human nature: to resist intended control over one's mind and body. While there was hegemony, enslaved people consenting to their new reality, there was assuredly some degree of aversion to that reality. It is not coincidental that our consideration of slavery begins in the Caribbean, the very area where sugar slavery would predominate more than anything else.

As for Cortés himself, Díaz reports that in Cuba he had "good Indians and encomienda" (buenos indios y encomienda) ( $H V, 38 \mathrm{a})$. He remembers Cortés proclaiming in Santiago de Cuba that he needed hands for his great enterprise. For compensation, the participants would receive gold, silver, riches, and "encomiendas de indios." For all this, the governor Diego Velázquez had license from His Majesty, the King $(H V, 39 a)$. The practice of remunerating with slaves was so ingrained, one could reason, as Díaz does, that Velázquez lost his famous dispute with Cortés because he failed to pay for his follower's services with "good Indians" (buenos indios) ( $H V$, 42a, 42b). As his men felt deceived, he lost their loyalty, a reality not lost upon Cortés. Velázquez did not seem to grasp the importance of winning friends with property, here, human property. In the end, he could not even count on the aid of his own relative, Juan Velázquez, precisely, "because he had not given him good Indians" (porque no le había dado buenos indios) ( $H V$, 46a). The feudal medieval idea of reciprocity becomes apparent here and he who offers land and possessions can expect loyalty. Since Velázquez did not offer suitable property, he did not receive loyalty from his men.

The "encomiendas de indios" may not have been legalized chattel slavery, but it took separation and hierarchization to another level since Indigenous people held in encomienda by definition owed something (labor, tribute) to the Spanish overlord who in return provided them with religious instruction. As Arturo Arias notes, after the Leyes de Indias were passed in 1542, "the encomienda became a backdoor method to justify slavery in the Americas." ${ }^{100}$ If Africans could be slaves, the Indigenous could be encomendados. Whether technically a slave, or an encomendado, the realities on the ground were

98 Jackson, Race, Caste, and Status, 4.

99 Wallerstein, The Modern World-System, 88.

100 Arias, Recovering Lost Footprints, 1:241. 
comparable and all-encompassing. The notion of bondage was totally ingrained in the forming Spanish colony, despite the Leyes de Burgos (1512) and the unfulfilled Nuevas Leyes, or New Laws (1542). This was so much the case that Spaniards could conceive of the reverse idea of Spanish slaves under the Maya. Oviedo mentions how Velázquez orders Cortés to release certain Spaniards (Jerónimo de Aguilar and Gonzalo Guerrero) captured in the Yucatan (see $H V$, 49a). Díaz narrates the story of these Spaniards held captive by certain caciques. Aguilar did not marry; he left with Cortés to become a point in the translation triangle that he formed with Cortés and La Malinche. ${ }^{101}$ Guerrero had taken a wife, he stayed.

The Spanish enslaved the Maya too. Bartolomé de las Casas, in his 1552 Brevísima relación de la destrucción de las Indias, reports cases of Maya being bartered for "wine, oil, vinegar, bacon, clothing and horses" (vino y aceite y vinagre, y por tocinos, e por vestidos, y por caballos). Even a Mayan king's son was sold off for a piece of cheese. ${ }^{102}$ Spaniards initially saw Yucatecs as a commodity; later, in 1532 and after they were trafficked to Peru, they became human fodder during the initial stage of the Forty-Years War the Spanish waged against the Inkakuna. The Maya were not the only Central Americans to end up in Peru. Jaime Wheelock Román reports that between 1527 and 1531, the governor of Nicaragua, Pedrarias Dávila (Pedro Arias de Ávila), sold Indigenous slaves from that region and introduced them into slave routes ending up in the Antilles and in Peru. ${ }^{103}$ Las Casas reports that when the Spanish began ripping apart the fabric of the K'iche' nation located in the lands today known as Guatemala, those inhabitants who did not have resources to meet tribute demands had only one choice before the new Spanish overlords: "giving them their sons and daughters, because other slaves they did not have" (dándoles los hijos e hijas, porque otros esclavos no los tienen) ${ }^{104}$ Even if Las Casas were exaggerating, as he was wont to do in the Brevísima relación as a rhetorical strategy to get on his readers' nerves and provoke positive change, the flow of his narrative gives a general idea of the goings-on during that time and the un-Christian abusive tactics Spaniards employed against people to garner wealth. As the early sociological thinker from Peru, Manuel González Prada, stated in 1904, “Although Las Casas' affirmations have been branded as exaggerated, it cannot be denied that thanks to the exploiter's greedy cruelty, in some American peoples, the weak element finds itself close to extinction" (Aunque se tache de exagerables las afirmaciones de Las Casas, no puede negarse que merced a la avarienta crueldad de los explotadores, en algunos pueblos

I0I Aguilar spoke Spanish and Yucatec, a Mayan language, La Malinche spoke the same Mayan language, as well as Nahuatl. Cortés would ask a question in Spanish, Aguilar would translate it into Yucatec, La Malinche would translate it into Nahuatl. The Nahua would respond in Nahuatl, La Malinche would translate the answer into Mayan, and Aguilar would translate it into Spanish for Cortés.

102 Las Casas, Tratados, 1:90-91.

103 Wheelock Román, Raíces indígenas, 30.

104 Las Casas, Tratados, 1:102-4. 
americanos el elemento débil se halla próximo a extinguirse). ${ }^{105}$ The facts are the facts and the flourishes are the flourishes, but the flourishes do not change the facts.

As a consequence of a mutual deeply held acceptance of ranked societies as normative, Spanish customs could be superimposed over Nahua, Yucatec, K'iche', and other Mesoamerican patterns. During the initial decades after the imposition of Iberian power, slaves mainly held the same status as in the pre-Hispanic era, yet as Cline cautions, just "how much their subordinate status changes in the colonial period is unclear." 106 The existence of precontact slavery suited the Spanish ethos, for to create slavery where none existed could have appeared less Christian and consequently less acceptable to the crown. As Charles Gibson points out, Spanish slavery could operate "under a guise of legitimacy whenever Indians could be shown to be occupying a 'slave' status already in Indian society-for this could be understood as a change of masters rather than as an initial enslavement."107 In Nahua regions, other forms of forced labor drew on custom. The dreaded repartimiento often "continued to follow the procedures of the indigenous coatequitl." ${ }^{108}$ Siméon's dictionary lists the coatequitl as a public works project, a community effort. ${ }^{109}$ As with the above-commented-upon mita, while the coatequitl was required labor, it was for the common good. This aspect changed when the Spanish appropriated the system because they employed it for personal gain, not for the common good as previously conceptualized. Nevertheless, the coalescing of European and Mesoamerican forms of servitude proved to be an effective synthetic system of subordination. Slavery became so widespread during the early colony, that slaves actually became property of other slaves in Mexico. ${ }^{110}$ The enduring sentence of human servitude fell upon millions of Mexicans with such force, legend has it, that even the barbaric hand of Hernán Cortés trembled. ${ }^{111}$ Notwithstanding the severity of these sub-human conditions, the Marquis of the Valley did not refrain from enslaving a great quantity of Nahua to rebuild Mexico City after he and his men had destroyed it. ${ }^{112}$

After the initial Spanish penetration and a new society began to establish new institutions, the number of Indigenous slaves began to decrease. Lockhart detects that the slave classes began to blend into the other lower social categories. First, with the demise of late antiquity's Wars of the Flowers, "one source of supply was gone." Second, a few decades after their arrival, early modern Spanish finally abolished Indigenous slavery "among sedentary peoples, relegating it to the nonsedentary fringes." ${ }^{113}$

105 González Prada, Obras, 3:200.

106 Cline, "The Spiritual Conquest," 463-64.

107 Gibson, The Aztecs, 221.

108 Gibson, The Aztecs, 227.

109 Siméon, Diccionario, 115a.

I 10 Moreno Toscano, "La esclavitud," 345; Gibson, Spain, 115.

I I I Benítez, “El español, conquistador y conquistado," 195.

II2 Sierra, Evolución política del pueblo mexicano, 43.

I 3 Lockhart, The Nahuas After the Conquest, 111. Gibson reports "slaveholding by Indians was a short-lived colonial institution. Quite expectably, it was forbidden by royal law." Gibson, The Aztecs, 154. 
Indigenous servitude continued after the 1540 s only as a detriment to rebellion, much (as we see in chapter 3) as Thomas More proposes.

\section{The Encomienda and the Imposition of Debt Peonage}

The encomienda was like a micronation that had its own lord who ruled over it like a fiefdom. ${ }^{114}$ The lord, or encomendero, "held Indians," not as property, but he did control their lives. This variety of servitude was similar to, but technically distinguishable from, short-lived Indigenous slavery (referred to above) and from long-lasting chattel slavery (discussed in the next section). The encomienda category refers to Indigenous peoples who are "entrusted to the charge of a Spanish colonist," who in turn, as Gibson explains, was "permitted to exact both commodity tribute and labor service."115 Keith offers the details: "With their large households, encomenderos required numerous Indians to serve as cooks, janitors, porters, and in other domestic capacities." ${ }^{116}$ Additionally, there was toiling in mines and later in the fields. In return, the encomendero took responsibility for the encomendados' religious instruction and consequently needed to employ a priest or other cleric to provide it. An essential difference between encomienda and chattel slavery was that the latter could be disengaged from Christianity (although it rarely was), while the former, from its inception, grew out of Christianity. Put another way, encomienda slavery by definition could not exist except in relation to Christianity. The Leyes de Burgos legally instituted encomienda slavery and drew a line between indios esclavos and indios encomendados. These leyes allowed for the forced Christianization of the encomendados as well as their forced relocation to achieve that end. Because of the investment required for his providing of Christian teaching, the encomendero, in return, would be entitled to "enjoy" "said Indians." In a word, this system exchanged Christian education for corvée labor. The leyes explicitly prohibit the sale of the Indigenous, differentiating encomienda slavery from chattel slavery, which saw subordinated peoples as tangible property. ${ }^{117}$

The encomienda served as a form of private enterprise, local in nature, and only sometimes involved in commerce with the motherland. Assuredly, this system was not a purely European innovation. As Leisa Kauffman notes, it was a Spanish structure adapted to local Indigenous realities and tribute collection systems. ${ }^{118}$ The mercantile aspect was a give-and-take process among people of European extraction, yet for the Indigenous, money and labor flowed one way, from them to the encomendero, his pockets, or perhaps to the pockets of his colleagues, the corregidor (the royal official), judges, the Church, or

II4 The standard reference is Simpson, The Encomienda.

II5 Gibson, Spain, 49.

I 16 Keith, Conquest and Agrarian Change, 41.

I 7 Altamira, “El texto de las Leyes de Burgos de 1512,” p. 33: ley 13; p. 40: ley 26; p. 27: ley 3; pp. 23-25: “El Rey” and ley 1; p. 26: ley 1.

I 18 Kauffmann, "Figures of Time and Tribute," 34. 
the royal coffers. For this reason, Keith describes the encomienda as a parasitic institution. ${ }^{119}$ The lines between encomienda and chattel slavery were not always clear. Robert Haskett points out, "the idea that all conquered people were war captives led to a blurring of distinctions between the encomienda and outright slavery." ${ }^{120}$ Nevertheless, as Pagden argues, the legal distinctions were clear, those people subjected to the former were not considered chattel, while those subjected to the latter were. ${ }^{121}$

While to all intents and purposes the situation of the Indigenous worker on the encomienda was a kind of enslavement akin to feudal privilege, we should not discount its capitalist features: cash crops, exploitation of laborers who were technically free-subjects of the king-and the shift, after 1549, from labor to tribute. ${ }^{122}$ Owen Worth describes this combination of mercantilism and markets as "the first form of capitalism." ${ }^{123}$ For any form of capitalism to exist, money had to be part of it. Indeed, some form of collective salary, el sesmo, seems to have been paid to workers on some encomiendas in Chile, ${ }^{124}$ and increasing numbers of silver miners at Potosí did receive a salary-even if it was not enough on which to live. However free the mitayo worker was to work on this encomienda or that, or later, this hacienda or that, he or she did not have the economic resources to leave the system. It is easy to speculate that the hacienda system grew out of the encomienda and with it came the hacienda store and the institution of debt peonage. ${ }^{125}$

Andeans organized their families and their communities into ayllu units and to the detriment of their traditions, the Spanish powers enacted tribute from them through a kuraka or other local leader. One way to avoid payment was to flee the ayllu. Encomiendas, and later haciendas, needed farm hands. The result was that the peasants fled their ayllukuna leaving those who remained behind shorthanded to meet with ever-increasing tribute demands. However, they did not find freedom. They were now called forasteros, or outsiders, and they ran right into other encomiendas, mines, obrajes, and perhaps even early haciendas that were in need of peones. ${ }^{126}$ There was a mighty force impelling these movements, but "few-Pagden frets-of the great apologists for the Indians registered any serious protest against this dislocation of the Indians tribal life."127 Thus, dislocation continued as the norm.

119 Keith, Conquest and Agrarian Change, 55.

I 20 Haskett, "Our Suffering with the Taxco Tribute," 453.

I2I Pagden, The Fall, 35.

122 Wallerstein, The Modern World-System, 92-94, see also Burga, Nacimiento, 133.

123 Worth, Rethinking Hegemony, 25, also 26.

I 24 Jara, “Una investigación," 240, 241.

125 For an interesting debate about where encomienda ends and where hacienda begins, see Lockhart, "Encomienda and Hacienda," in Of Things of the Indies, 1-26, and a response to it in Keith, "Encomienda, Hacienda and Corregimiento."

I 26 See for example, Keith, Conquest and Agrarian Change, 30.

127 Pagden, The Fall, 35. 
An ancillary feature of the economic thrust was the deculturation and inculturation of these workers. Fernando Ortiz, in his Contrapunteo cubano del tabaco y el azúcar (Cuban Counterpoint: Tobacco and Sugar) describes this cultural give and take as transculturation. The result was a brand-new culture, part hybrid, and part something new derived from previously unimagined cultural combinations. Elements of the new transcultured identity allowed the infusion of coloniality, and peons, yanaconas, mitayos, and pongos accepted their condition. At least at the onset of imperial influence, on many of these farms, the workers were yanaconas, yanakuna in Qheswa, literally service men and women required to provide feudal-like labor. Gibson writes, this system "has most commonly been studied as a derivative of feudalism, which it was." ${ }^{128}$ Precontact yanaconaje survived into the Forty-Years War in Peru, entered into the all-enveloping colony, survived after independence, and as José Matos Mar demonstrates, it eventually morphed into sharecropping on the coast in the twentieth century. ${ }^{129}$ The emerging feudal structure encased in the encomienda evolved over the long term, becoming, before the nineteenth century, the system known as debt peonage, slavery by another name, albeit liberated from the notion of property. Yet, already in the sixteenth century change was in the air. One drastic modification in policy occurred, as Burga explains, when "tribute began to be paid in products, not in work, as had been the case in the Inka Empire" (el tributo comienza a pagarse en productos, no en el trabajo, como se hacía en el imperio inca). ${ }^{130}$ The essential hacienda-like feature of debt peonage that established monetary debt at unfair levels relative to the value of products was being practiced during the early modern era, as lamented by a notable chronicler from that period, Felipe Guaman Poma de Ayala. In his overview of the kingdom of Peru, he laments thusly, "if [the worker] loses ten sheep (or llamas), [the foreman] will make him pay twenty, making him forfeit a day's wages so there is no food or nourishment and his wife and children are kept occupied" (ci pierde dies carneros haze pagar beynte carneros y los quita toda su jornal y no les dan de comer ni alemento y ocupa a sus mugeres e hijos). ${ }^{131}$ There is much to lament about the expansion of the debt bondage system between the sixteenth and twenty-first centuries. It did, however, represent a step away from chattel slavery and from feudal-like yanakuna or coatequitl service. While these three appalling forms of severe service share the impossibility of legal escape, the introduction of money takes a (small!) step toward a market system and away from humans as property. This market system has a cultural impact. People whose parents and grandparents saw things in terms of the ayni, a work ethic based on reciprocity, were beginning to see themselves as part of the monetary system. This was not the case with all people, but with some people. The disengagement from chattel slavery for Amerindians may have allowed them greater movement, albeit within the restrictive realm of debt, while conversely making more room for chattel slavery on the backs of black people.

128 Gibson, Spain, 156-57.

129 Matos Mar, “Sharecropping," 163-67.

130 Burga, Nacimiento, 133.

I3I Guaman Poma, Nueva crónica, 525 [539]. 


\section{Chattel Slavery's Philosophical Underpinnings}

The even more severe institution of chattel slavery complemented the colonial function of the encomienda. ${ }^{132}$ This variety of slavery occurs, in the words of John Papadopoulos and Gary Urton, when "the body itself [becomes] an object of desire, something that can be possessed and owned, something with a fungible value-an exchange value-all its own." ${ }^{133}$ Papadopoulos and Urton isolate the two defining characteristics of chattel slavery, property and value; the value at which certain properties are held that are determined by the marketplace. Since the days of the Romans and before, there were markets and there were slaves. There was trade and there was tribute. In a word, the European World-System was not born in a day, a year, or a century. The exchange-based and the colonialist systems have operated side by side-assisting each other, some might add-for millennia. However, in the European world, there were ways of making softer the cruel inhuman push to conquer and enslave. In effect, those softening discourses are chapter 3's primary interest. Before getting to them, we first need to discuss chattel slavery's philosophical underpinnings to understand what grievances grabbed the Renaissance reformers' interest.

Human bondage was an integral element of society before and during the sixteenth century in Europe, paralleling what was happening in the Western Hemisphere where it also existed. In the Old World, Greeks and Romans practiced slavery as did early Africans, and medieval Europeans and Muslims. William Phillips puts this in perspective: "During the thousand years from the end of the Roman Empire to the beginning of European expansion in the Atlantic, slavery was a social and physical reality in the Christian world, and it was reinforced by contact with the highly developed slavery of the Muslims." ${ }^{134}$ The practice was widespread. As Dirk Hoerder makes clear, "Islamic, Jewish, Byzantine, and Latin Christians peoples all practiced state slavery (administrative, military, or fiscal) and private slavery (productive, commercial, or domestic)."135 The slaves, in Weaver's words, "became important mercantile commodities."136 Martin A. Klein tempers the horror of bondage when he suggests "it was unlikely, however, that many medieval or early modern societies were completely dependent on slave labor." ${ }^{137}$ Nevertheless, the practice was widespread and the slavery-infused World-System incontrovertibly found itself largely engaged in human commerce across the sea. As Wallerstein observes, it had to originate "from a region that was outside its world-economy so that Europe could feel unconcerned about the economic consequences for the breeding region of widescale removal of manpower as slaves. Western Africa filled the bill best." ${ }^{138}$ Wallerstein's

I32 On slavery in a comparative context, see Bergad, The Comparative Histories of Slavery; also Inikori and Engerman, "Introduction," and Klein and Vinson III, La esclavitud africana.

I33 Papadopoulous and Urton, "Introduction," 26.

I34 Phillips, Slavery from Roman Times, 3.

135 Hoerder, Cultures in Contact, 40.

136 Weaver, Latin America in the World Economy, 12.

137 Klein, "The Impact of the Atlantic Slave Trade," 34.

I 38 Wallerstein, The Modern World-System, 89. 
observation coincides with Pagden who adds that slaves "came from regions where the Spanish crown had no political commitments." ${ }^{139}$ Thus unfolded history as we know it.

As we will see in the next section, Columbus brought slaves from the Caribbean with him back to Seville in the 1490s to set up that possibility as commerce. Later, as Laird Bergad points out, some 200 slaves aided Hernán Cortes in his push to subdue Tenochtitlan. ${ }^{140}$ Then they came to Peru. Indeed, Africans were second only to Amerindians in Lima and Mexico City. ${ }^{141}$ Besides Mexico and Peru, slaves became part of the fabric of the new society forming in northeastern Brazil and reached every place Spaniards and Portuguese settled. ${ }^{142}$ While the sugar enterprises in the Caribbean were not of the magnitude of the haciendas that were to follow, they did set the patterns for those later centuries. Besides Caribbean and Brazilian sugar, the discovery of silver in Potosí (present-day Bolivia) and Zacatecas (Mexico) as well as the ongoing Indigenous demographic collapse led to even more North and Sub-Saharan Africans being imported. ${ }^{143}$ This is not to say that the rise of chattel slavery was inverse to the decline of autochthonous populations. Seijas and Sierra Silva underscore, “Mexico's indigenous population only recovered to its 1580s levels at the start of the nineteenth century." ${ }^{144}$ Furthermore, the human trafficking and exploitation of Africans and their descendants predominated so much that Seijas and Sierra Silva talk about "the centrality of slavery in Mexican history." ${ }^{145}$ The "centrality of slavery" means it was crucial for the system's functioning. Hence, Bergad concludes that slavery became "essential to the colonial system." This was so because it entered many facets of life. Bergad explains, "it was highly diversified, and slaves were found in every economic activity, urban and rural." By the year 1650, some 340,000 slaves had been imported to Spanish-speaking areas of the Americas, and 225,000 to Lusophone areas. ${ }^{146}$ All told, 1.1 million Africans would come to Spanish-speaking areas. ${ }^{147}$ More arrived in the form of newborn babies. Slavery developed as the needs of commerce dictated, but the legal system was likewise a decisive factor.

As with any imperial enterprise, the question of law is paramount to justifying it. John F. Schwaller points out that there were two types of international law that guided (should have guided) human activity during this time, one code governing relations among European states and the other between the European states and their possessions in Las Indias. ${ }^{148}$ The latter is of concern here. One of the underpinnings of the slave system was the belief in a natural order of laws that was immutable. Sixteenth-century explorers, conquerors, and theorists held this view of things, which during that time, found in

139 Pagden, The Fall, 33.

140 Bergad, The Comparative Histories, 33-35.

I4I Bergad, The Comparative Histories, 37-38.

142 Bergad, The Comparative Histories, 36, 38.

143 Bergad, The Comparative Histories, 36; also Chasteen, Born in Blood and Fire, 52.

144 Seijas and Sierra Silva, "The Persistence of the Slave Market," 311.

145 Seijas and Sierra Silva, "The Persistence of the Slave Market," 307.

146 Bergad, The Comparative Histories, 15, 50-51.

147 Klein and Vinson III, La esclavitud africana, 144.

148 Schwaller, "Introduction," xiv. 
Aristotle a philosophical and legal basis to buttress the ideological foundation of their enterprise. His ideas had become so accepted from the thirteenth century on that he was known simply as "The Philosopher." This St. Thomas Aquinas (1225-1274) had learned from his teacher, St. Albert the Great. ${ }^{149}$ In Spain, for example, the thirteenth-century king Alfonso el Sabio quotes him in the foundational Siete partidas, and the fourteenthcentury poet Juan Ruiz, the Archpriest of Hita, comments on an Aristotelian text in his famous Libro de buen amor. ${ }^{150}$ This footprint continued through the Renaissance where it established itself as a dominant strand of empire-building political and social thought.

The Politics, which favored a natural basis for justifying slavery, became one of the central texts giving form to this convention. Consider this passage:

It is also from natural causes that some beings command and others obey, that each may obtain their mutual safety; for a being who is endowed with a mind capable of reflection and forethought is by nature the superior and governor, whereas he whose excellence is merely corporeal is formed to be a slave; whence it follows that the different state of master and slave is equally advantageous to both. ${ }^{151}$

Aristotle reasoned out his "natural" slavery defining the "master" as an integral being, maintaining that the "slave" was only partially whole, needing the former's mind for integrity: "the slave is not only the slave of the master, but nothing else but that." ${ }^{152}$ This kind of deductive reasoning is the result, according to J. Donald Hughes, of the attitudes of the ancient Greeks who "tried to understand nature rationally, not mythically".153 Based on a logical methodology, Aristotle assigns the qualities of perfection to nature, allowing for "nothing either imperfect or in vain." 154

Such an ideology was useful for the ruling elite because according to it a slave devoid of reason or soul needed to be governed by the rational master. ${ }^{155}$ Because he or she lacks a soul, to use James A. Weisheipl's phrase, he or she is "a non-living thing [that] simply moves of itself and not by itself." ${ }^{\prime 156}$ While Aristotle did not clearly lay out whether

149 Daly, "Revelation," 24.

I50 Ruiz, Libro de buen amor, stanzas 71-73.

I5I Aristotle, The Politics, 1252a-1252b, p. 2.

152 Aristotle, The Politics, 1254a, p. 7.

153 Hughes, Ecology, 58.

154 Aristotle, The Politics, 1256b, p. 14.

155 Aristotle, The Politics, 1252a, p. 2; 1254b, p. 8. A hierarchic system would create an imbalance that arises from the "have-nots" aspiring to higher status. Some interpretations of Aristotle (relying upon a reading of his Nicomachean Ethics) have caused certain commentators to come to conclusions such as Boruchoff's: "Aristotelian justice rests upon the precept that society, like nature and the arts, must maintain a balance between its various elements. Thus, each of the four 'just causes' Sepúlveda outlined posits war as a means of rectifying an inequality arising from the Amerindians' prior actions: their use of force, unlawful seizure of property, sinful deeds, and 'inhuman' or 'barbarous' instincts" ("Beyond Utopia," 363). Although Boruchoff construes Aristotle's political philosophy as one of balance, judging a culture "barbarian" implies a superiority complex on the part of one group which imparts a value judgment on the other.

156 Weisheipl, “Aristotle's Concept of Nature," 147. 
a slave was a human or not, he did propose that any bondsman refusing to submit to Greek rule could be subjected to a just war. ${ }^{157}$ Following the Aristotelian logic, the victor is the victor because of superior and therefore natural abilities. Thus, "it seems that force never prevails but in the consequence of great abilities." ${ }^{158}$ He then goes into the legal arguments that always come back to natural factors. In a word, all notions of slavery can eventually be traced to the natural determinants that cause certain people to be slaves.

Although it is not explicit, as José Rabasa cautions, it is easy to deduce from Aristotle a concept of slavery grounded in national ethnicity. ${ }^{159}$ This is what Pagden is getting at when he states it was grounded in culture. ${ }^{160}$ Early in the Politics (the second chapter of the first book), Plato's disciple quotes the poets who believe "it is proper for the Greeks to govern the barbarians, as if a barbarian and a slave were by nature one."161 As is obvious, Aristotle applied this designation to those who were not of the Greek culture. ${ }^{162}$ If Greeks are Greeks and barbarians are barbarians, what is the characteristic that distinguishes them if not ethnicity, even if this category and language had yet to be conceived? Elsewhere, in order to preclude classifying persons of nobility as slaves, Aristotelian logic asserts: "we must acknowledge that there are some persons who, wherever they are, must necessarily be slaves," while people "of noble descent" "in no situation" can be. ${ }^{163}$ While Aristotle does not talk about ethnicity (a metric not yet known to the Greeks) and logically avoids racial notions (a concept not dominating the social science scene until the late nineteenth century), the idea of Greeks and Barbarians divided essentialistically from each other in nature is just another way, perhaps the first way, to create these categories. ${ }^{164}$ Since Aristotle was "the Philosopher," these ideas were certainly read by Renaissance historians, theologians, and lawyers who were living and breathing in a resurgence of classical archetypes.

During the late Middle Ages, as Pagden explains, Europeans considered nonEuropeans such as Berbers, Turks, and Ethiopians as barbarians. He has found additional evidence suggesting that certain Europeans regarded Europeans of other etnias

157 Aristotle, The Politics, 1256b, p. 14.

158 Aristotle, The Politics, 1255a, pp. 9-10.

159 Rabasa, “Utopian Ethnology in Las Casas,” 268-69.

160 Pagden, The Fall, 16, 19, 20.

16I Aristotle, The Politics, 1252b, pp. 2-3.

162 Mignolo takes issue with the use of the term culture, which he defines as "a key word of colonial discourses classifying the planet," Local Histories, 15. His argument is convincing, yet I have found no other word free from colonial connotations because other signifiers such as tribe, ethnic group, and etnia also seem to be tainted.

163 Aristotle, The Politics, 1255a, p. 10.

164 The notion of race arrived in Europe in waves. In France, "A New Division of the Earth, according to the Different Species or Races of Men who Inhabit it" was published in 1684, Boulle, "Francois Bernier," 11. Hannaford suggests racial consciousness became institutionalized in three stages: 1684-1815, when writers use race "as an organizing ideal," 1815-1870, "when the map of Europe was reconstructed to restore things to their legitimate prerevolutionary 'natural' origins," and finally, 1870-1915, "the high point in the idea of race," Race, 187. 
(Irish and Normans) as barbarians. ${ }^{165}$ Canonized from Aristotle's Politics, this terminology became widespread during the sixteenth century. In Institutio principis Christiani, or The Education of a Christian Prince, for example, Erasmus of Rotterdam remarks how on occasion princely power is hereditary, a "custom among some barbarian peoples in the past (according to Aristotle)." ${ }^{166}$ We notice that in Erasmus here barbarians are a thing of the past, not of the present. The Spanish authors Bartolomé de las Casas and Antonio de Guevara also used the word. The latter became famous in literary circles, among other reasons, for two chapters from his book Relox de Príncipes. These offered a critique of empire not easily emitted from within the empire. Rather than in a direct approach, the criticism appears as a parable that operates through analogy. In this story, a Danubian peasant addresses the Roman senate and denounces imperialism, the violence it implies, and the effect it has upon the people governed. Guevara was arguing against what was then called the Conquest, falling into a category we might call pacifist, or even progressive. For example, as Santa Arias takes note, Guevara's thesis was that those who reside in nature-read Indigenous people-can be happier than those who live under empire. ${ }^{167}$ However, Guevara seems to have vacillated in his use of the term barbarian since in another version of this story integral to another work, his Libro áureo, the author, or the editor, deleted the term. Hence, in the Relox version people, "may be Greek, or barbarian, or Roman" (que sea griego, que sea bárbaro, que sea romano), but in the Libro áureo, the label is suppressed and peoples are classified as simply being "Greek or Roman" (que sea Griego que sea Latino). ${ }^{168}$ The assertion "we demand obedience of the untamable barbarians" (dimos la obediencia a los indómitos bárbaros) is likewise suppressed in the Libro. ${ }^{169}$ While we cannot know with absolute certainty which of the versions is earlier, or if the Libro áureo was a pirate edition as David A. Lupher asserts, we can conclude that Guevara was comfortable with the term, at least in some points. ${ }^{170}$ Yet if the Libro áureo was an earlier version dating from 1518-1524 as Lupher suggests, it may explain why the authorities were disinclined to allow its publication. We would then suspect that the term was gaining wider usage during those years.

This linguistic usage of the word barbarian took the same form during the European enterprise in Abya Yala. Given the colonial mentality in which the concepts of fatherland

165 Pagden, The Fall, 15. The early modern period in Spain could be viewed as beginning with the marriage of Ferdinand and Isabella uniting Aragon and Castile in 1469. See Cowans, Early Modern Spain, 1.

166 Erasmus, The Education of a Christian Prince, 5; "quod et olim apud barbaras aliquot nations fieri solitum testator Aristotles" (Institutio principis christiani, 136).

167 Arias, Retórica, 64.

168 Guevara, Relox de príncipes, 2:637; Guevara, Libro áureo de Marco Aurelio, 1:125; also Guevara, Libro áureo in Bulletin Hispanique, ed. Foulché-Delbosc, 120.

169 Guevara, Relox de príncipes, 2:639; Guevara, Libro áureo de Marco Aurelio, 1:127; also Guevara, Libro áureo in Bulletin Hispanique, ed. Foulché-Delbosc, 122. There is one more case where Guevara describes the Germans as "las gentes tan bárbaras," which is completely suppressed in the Libro, Guevara, Relox de príncipes, 2:642.

I70 Lupher, Romans, 51. 
(patria) and nation linked to cultural groups, ${ }^{171}$ neo-Aristotelians did not have difficulty in equating Spaniards and Greeks while describing the ethnicities of America as barbarians. In the end, as Pagden maintains, "It was only this identification of the natural slave with the barbarian that made the theory of natural slavery of any use in the discussion over the nature of the American Indian." ${ }^{172}$ During the wars of annexation, even detail-oriented chroniclers such as Pedro Cieza de León saw nations as civilized or barbarian. Referring to the Isla del Gallo, or Gorgona Island, where Pizarro and his "thirteen of fame" took refuge after drawing the famous line in the sand, Cieza de León refers to its inhabitants as "barbarian peoples" (gentes bárbaras). ${ }^{173}$ Yet these were sedentary peoples with an organized urban structure. Cieza himself is aware of this and he observes that houses are fortified inside a wooden fence (tienen las casas armadas en grandes horcones a manera de baruacoas o tablados). ${ }^{174}$ A wooden fence implies permanence and a feeling of community and it creates a town protected from outsiders as well as an implication of local laws and customs that govern the community. The idea of a town goes to the Greek ideals of polis and civis. ${ }^{175}$ Therefore, it is difficult to fathom how Cieza and his compatriots could consider such sedentary people "barbarian," except as part of a conscious or subconscious coloniality needed to justify in their minds what they were saying and doing. They were looking at things through an imperial lens. Cieza's depiction of these people as barbarians implies an inherent denial of their civil life.

The idea of "towns" was apparent to Cieza de León on other occasions. On his trek through the lands that would eventually become the modern republic of Colombia, he describes certain valley city-states he had been observing on his way to Cali, "there are many Indian towns comprised of different nations and customs, very barbarian" (ay muchos pueblos de Indios de diferentes naciones y costumbres, muy bárbaros). ${ }^{176}$ Cieza de León concedes the status of "nation" to "barbarian" peoples, which was not the case with the Nahua-centric Tlaxcaltecan historian Diego Muñoz Camargo, who revealed a lack of sympathy toward nomadic peoples he described as "barbarians" to whom he denied the status of "nation." 177 Unsurprisingly, the denomination is offensive to those who find themselves described by it. If we turn to an early seventeenth-century text for a reaction, the response is unmistakable. The Texcoco-focused historian Fernando de Alva Ixtlilxóchitl repudiates well before 1640 the "barbaric interpretation" of the name Chichimecatl that resulted from painting and how the term sounds in the Nahuatl language. For him, the proper name "Chichimecatl" applied to his people from their origin

I7 I See Monguió, "Palabras e Ideas."

172 Pagden, The Fall, 47.

173 Cieza de León, Crónica del Perú: primera parte, fol. 14 [iiii], p. 32.

174 Cieza de León, Crónica del Perú: primera parte, fol. 14 [iiii], p. 32.

I75 See, for example, Pagden, The Fall, 15.

176 Cieza de León, Crónica del Perú: primera parte, fol. 40v, p. 89.

177 Muñoz Camargo, Historia de Tlaxcala, 104. 
negated the meaning of barbarian from it. ${ }^{178}$ This ethnonym cannot mean "barbarian," a word applied only with injurious intent.

While there was a theorizing of the "barbarian" in the twentieth century that deconstructed notions of barbarism, there was previously a theorizing of "barbarians" that constructed inferiority for certain kinds of peoples. ${ }^{179}$ The theorizing of "barbarians" forms a kind dualism, us against them, as opposed to a more inclusive "together" which was not the norm. Bringing this all together, we can encapsulate the dualist architecture of this kind of thought. While in the Greek world, Pagden reminds us, there existed "two distinct forms of slavery, the civil and the natural," it was the natural one that offered "the means to explain why it was morally right for one nation-in the case Greeks-to enslave members of another." ${ }^{\prime 80}$ Slavers and defenders of slavery used the theory of natural slavery to justify its use in the so-called Conquest. Francisco González de Oviedo, an important official chronicler, coincides with Cieza's use of the term "barbarian." Pagden explains: "The Indians, he thought, most clearly resembled the 'Ethiopians' - the barbarian inhabitants of a vague geographical area that spread from the Atlas Mountains to the Ganges - and Aristotle's favorite barbarians, the Thracians." ${ }^{181}$ Besides the use of this term as a pejorative, Oviedo sets up the Western discursive strategy that Edward Said would later describe as Orientalism, which establishes "a kind of intellectual authority over the Orient within Western culture." ${ }^{182}$ By establishing authority over the East, by comparison, an authority envelops Amerindians. We know now that these people's ancestors many millennia ago migrated from the East via Siberia and Alaska. ${ }^{183}$ Internal colonialism later incorporates this Orientalist paradigm into its tenants, as with Domingo Faustino Sarmiento's discourse. ${ }^{184}$

But writers solely concerned with documenting and justifying the Conquest, such as Cieza de León, Bernal Díaz del Castillo, or Juan Ginés de Sepúlveda, were not the only ones active at that time. Reformists, idealists, and liberating thinkers would push social slavery into the discourse as a starting point to soften the binary structure informed by the doctrine of natural slavery. Ironically, if naturalist theories of slavery were dualist (Greek-barbarian), they formed another dualism with social slavery. This dualism functioned oppositionally between essentialist subordination and social subordination. Awareness of that oppositional dualism represents a first step toward liberation

178 Alva Ixtlilóchitl, Obras históricas, 2:37.

179 Within his attempt to conceptualize twentieth-century theorizing of the barbarian, Lund consults Wallerstein, Dussel, Mignolo including precursors Candido, Ortiz, and Malinowski. Lund, "Barbarian Theorizing," 54-72. Certainly, new language for old paradigms continues to appear: "socialism" and "lack of democracy" take on the functions of the old term barbarian.

180 Pagden, The Fall, 41.

18I Pagden, The Fall, 25.

182 Said, Orientalism, 19.

183 Lewis, Jr., et al., "Mitochondrial DNA and the Peopling of South America."

184 Sarmiento, Facundo, 75. We should not be too hard on Sarmiento since he was writing in the middle of a civil war of words and acts. Lund begins "Barbarian Theorizing" with Sarmiento. 
thinking. Finally, all forms of slavery, natural, social, and encomienda (which was social) formed yet another dualism, the greatest dualism of all, the dualism between the materiality of slavery and idealism that worked against all forms of social subordination.

One of the greatest stains on the history of humanity is slavery, whether directed toward "barbarians" or not. Aristotle's ideas furnished a philosophical foundation to govern the pyramidal social structure in which the Amerindians found themselves at the bottom, just above the Africans. We are not concerned here with the details of the theoretical debates and hearings, since Hanke, Pagden, and other scholars have excellently dealt with them. ${ }^{185}$ With the birth of a new multiethnic society during the sixteenth century, natural notions of slavery began to shift somewhat to allow for social ones that noteworthy early modern thinkers developed and popularized. This trend was concomitant with involuntary servitude beginning to disappear on the European continent (but not in Africa and the Indies), a decline that coincided with the rise of feudalism in the Americas. ${ }^{186}$ Given slavery's long arc, it is instructive to return to the moment when one of its central underpinnings began to weaken, when the convention of natural slavery was recast, however slightly, as a social one.

\section{Columbus: One Small Step beyond Aristotle}

With Christopher Columbus's voyages, the long sixteenth century begins, and early modernity arrives in Abya Yala. Slavery was a well-established practice in Columbus's world and it constituted a consequential attribute of transoceanic crossings. It is not so strange that Columbus would be familiar with human servitude. His biographer Samuel Morison describes "coffles of Negro slaves" that the Genoese probably saw upon his arrival at Lisbon in 1477. ${ }^{187}$ Columbus's acceptance of this practice appears in the briefs that he wrote to the Catholic Kings, Ferdinand and Isabella. To pay for the enormous expenses associated with his enterprise, the explorer recommends selling slaves. He sets his ideas down in a 1494 memorial:

Your Majesties could give license and permission for enough carvels to come every year to bring the above-mentioned livestock, other necessities of life, and things to populate, and to make use of the land. And this, at reasonable prices for your costs, could be paid for with slaves from these cannibals, people so fierce, clever, well-proportioned, and of very good understanding, that once removed from that inhumanity, we believe that they will be better than any other slaves.

[Sus Altesas podrán dar liçençia e permiso a un número de carabelas suficiente que vengan acá cada año, e trayan de los dichos ganados e otros mantenimientos e cosas de poblar el campo e aprovechar la tierra, y esto en precios razonables a sus costas de los que les truxieren, las cuales cosas se les podrían pagar en esclavos d'estos caníbales, gente tan fiera e dispuesta e bien proporcionada e de muy bien entendimiento, los

185 For those Spanish debates, see Hanke, The Spanish Struggle and his Aristotle; also Pagden, The Fall and Lupher, Romans in a New World.

186 Davis, The Problem of Slavery, 7, 37.

187 Morison, Admiral of the Ocean Sea, 32. 
cuales quitados de aquella inhumanidad creemos que serán mejores que otros ningunos esclavos. $]^{188}$

This acceptance of vassalage was part of an already established Weltanschauung that the Great Navigator never questioned. Morison explains: "It was a conception founded on the Spanish enslavement of Guanches in the Canaries, and on the Portuguese enslavement of Negroes in Africa, which Columbus had observed and taken for granted, and which the Church condoned." ${ }^{189}$ After a close reading of his diary, Beatriz Pastor concludes that in his mind those people went through a "gradual transformation into potential merchandise." ${ }^{190}$ Given his early life experiences, it is not surprising that Columbus would objectify the people he encountered. Columbus's attitude, similar to his cataloging of the Native Americans as "Indians," would survive for centuries.

His idea of slavery, like Aristotle's, drew on the perception of cultural distinctiveness. Different peoples behave differently. Behaviour was another factor, Pagden concludes, that Greeks considered when they dislocated themselves from other peoples who they did not consider Greek. ${ }^{191}$ It follows logically for the colonizers then, that "once removed from that inhumanity," Amerindians could become better slaves. If their behaviour changed, they could become less barbarian. Regrettably, Columbus does not fully take the next step and consider that being "removed from that inhumanity" might make them consonant to Spaniards (or Greeks).

Columbus's acceptance of slavery has made him a villain in the eyes of some commentators. But when viewed in terms of Aristotelian philosophy, a gray nuance filters into black and white concepts of the man. Notwithstanding an acceptance of bondage, Columbian abstraction on this topic does represent a small advance over Aristotle's philosophy, so ingrained in the conquering ideology. First, Columbus describes slaves as having "very good understanding." This superlative mental capacity puts the Columbian slave at a distance from the Aristotelian one, "whose excellence is merely corporeal." The Columbian model of the slave, ironically, can also reflect characteristics Aristotle credits to the master. With "very good understanding," it follows that he could be endowed, un-Aristotelianly, with a "mind capable of reflection and forethought." Second, Aristotle does not believe in a slave's ability to self-perfection because he who "is a slave by nature" cannot escape the natural status quo. As mentioned, Columbus's views differ from the Philosopher's because those unfortunate souls only had to be "removed from that inhumanity" and they could be "better than any other slaves." Hence, their condition becomes dynamic, not static. In the same Memorial, Columbus clarifies that by sending certain Caribs to Spain for instruction and baptism, they could be purged of "that inhuman custom" (aquella inhumana costumbre) of cannibalism, and they could

188 Colón, Textos y documentos, 153. Spanish was a second language for Columbus and consequently we find the adjective "buen" confused with the adverb "bien" in the expression "muy bien entendimiento."

189 Morison, Admiral of the Ocean Sea, 291.

190 Pastor Bodmer, The Armature of Conquest, 41.

191 Pagden, The Fall, 18, etc. 
learn to be translators. ${ }^{192}$ Translators! Undoubtedly, Columbus had them in mind as translators to further his and Castile's economic goals. But someone who could oscillate between dissimilar languages surely has developed a mental capacity that supersedes Aristotelean barbarism. Fortuitously, Columbus's model based on the needs of the moment destabilizes the natural model of slavery because it exposes the plain truth that slaves can ameliorate their level of "civilization." If the people enslaved had but to be dislodged from the "inhumanity" of the Indias Occidentales to improve their lot, then it follows that Columbus could visualize civil society's refining impact on a slave. The Admiral had begun to think in a way that would allow him to begin to believe in the perfectibility of those so vulgarly called "Indians." ${ }^{193}$ This small step of awareness creates an opening through which others can pass and begin the decolonial project. The gulf between Aristotle and Columbus demonstrates how the idea of slavery was less rigid in the mind of the latter. The idea that a slave could have a mind with the necessary gifts for translation and improve him or herself results, perhaps, from the power of the relatively more enlightened Renaissance over Columbus.

Columbus is relevant here because not only was he influenced by the Renaissance, he in turn also influenced the Renaissance, in a general and in a specific sense, because a young Bartolomé de las Casas saw Columbus exhibiting seven surviving Taínos in Seville, because his father accompanied Columbus on his second transoceanic voyage, and because he later acquired access to Columbus's papers and he transcribed and abstracted the diary of Columbus's first voyage. ${ }^{194}$ Certainly something survived of Columbus in Las Casas. Paolo Emilio Taviani recognizes that the celebrated navigator was neither Medieval nor Renaissance since he straddled the two ages. ${ }^{195}$ Although he is capable of moving beyond the inelastic Aristotelian concept to see slaves as a social, not natural, category, he is still incapable, however, of conceptualizing a symmetry of dissimilar peoples, part and parcel of progressive thought during the Renaissance.

192 Colón, Textos y documents, 153.

193 Las Casas (Apología, 15) was the one who first called the term "Indian" vulgar.

194 Giménez Fernández, "Fray Bartolomé de las Casas," 68-69; Dunn and Kelly, "Editor's Introduction," 3-14.

195 Taviani, “El hombre Colón," 92. 
